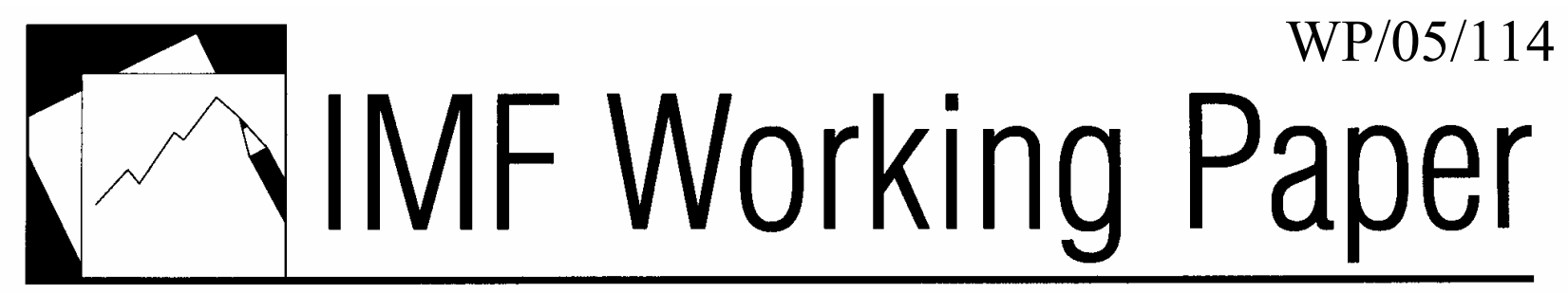

\title{
Latin American Central Bank Reform: Progress and Challenges
}

Agustín Carstens and Luis I. Jácome H. 


\title{
IMF Working Paper
}

Office of the Managing Director

\section{Latin American Central Bank Reform: Progress and Challenges}

\author{
Prepared by Agustín Carstens and Luis I. Jácome H. ${ }^{1}$
}

June 2005

\begin{abstract}
This Working Paper should not be reported as representing the views of the IMF. The views expressed in this Working Paper are those of the author(s) and do not necessarily represent those of the IMF or IMF policy. Working Papers describe research in progress by the author(s) and are published to elicit comments and to further debate.

This study takes stock of the institutional reform of monetary policy in Latin America since the early 1990s. It argues that strengthening the legal independence of central banks, together with macroeconomic policies, was instrumental in reducing inflation from three-digit annual rates in the 1990s to single-digit territory in 2004. The paper also discusses the main challenges of monetary policy today, namely, achieving price stability, restoring market confidence in domestic currencies, and sticking to policy consistency despite adverse effects of the volatility of capital flows. Finally, recurrent banking crises and lack of fiscal discipline are identified as the main risks for the success of monetary policy in Latin America.
\end{abstract}

JEL Classification Numbers: E42, E52, E58

Keywords: Central bank independence, inflation, monetary policy, Latin America Author(s) E-Mail Address: acarstens@imf.org, ljacome@imf.org

\footnotetext{
${ }^{1}$ Agustín Carstens is a Deputy Managing Director of the International Monetary Fund. Luis I. Jácome H. is a Senior Economist in the Monetary and Financial Systems Department of the International Monetary Fund and Adjunct Associate Professor at Georgetown University. The authors wish to thank Alain Ize, Robert Rennhack, and Roberto Steiner for their comments on a previous version of this document, and to Nada Oulidi for providing valuable research assistance.
} 
II. The New Institutional Framework for Monetary Policy .................................................5

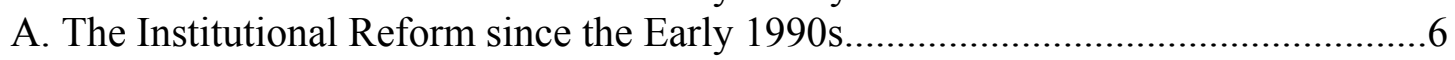

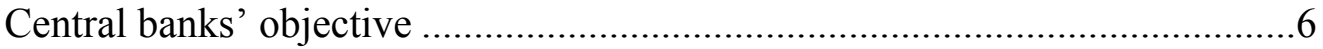

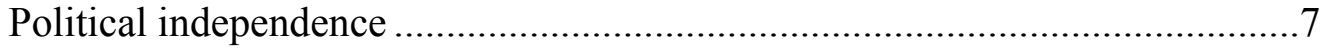

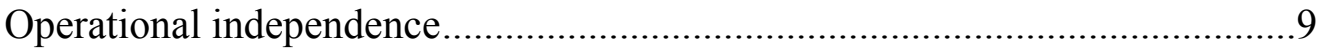

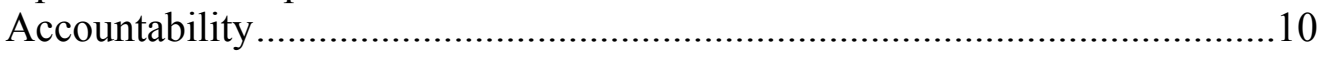

B. How Independent Are Central Banks in Latin America? ...................................11

III. Legal Central Bank Independence and Macroeconomic Trends in

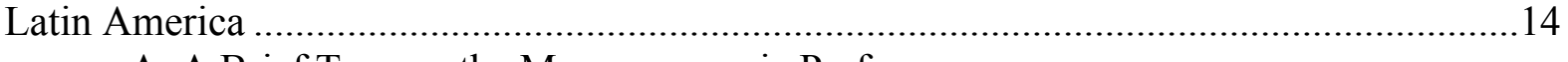

A. A Brief Tour on the Macroeconomic Performance

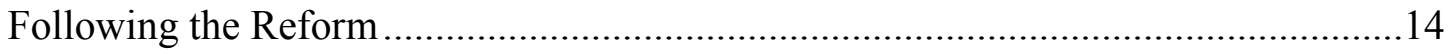

B. Has CBI Played Any Role in Reducing Inflation in

Latin America?

IV. Changes in the Policy Regime and Innovations in the Operating

Framework of Monetary Policy ............................................................................... 17

A. Changes in the Monetary Policy Regime........................................................ 18

B. The New Operational Framework ..............................................................20

V. Challenges Facing Latin America's Central Banks......................................................21

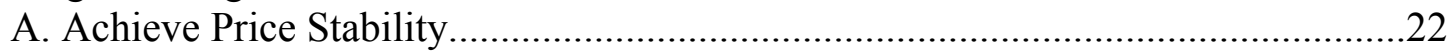

B. Restore Confidence in Domestic Currencies .....................................................26

The case of countries that have tied their currency to the U.S. dollar .............26

The case of countries that have a legacy of past periods of inflation ..............28

C. How to Cope with Capital Inflows While Maintaining

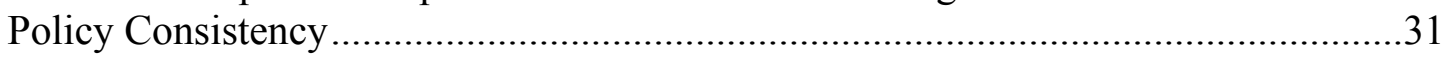

D. The Perils of Financial System Weaknesses and the

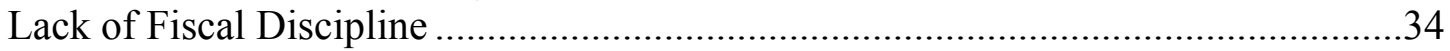

The need to preserve sound financial systems ...........................................34

The importance of having strong public finances .......................................37

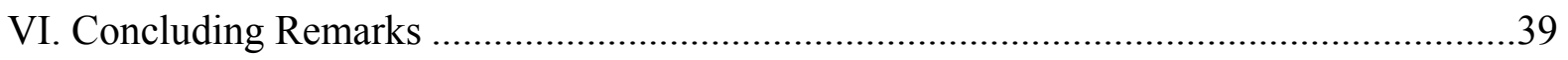

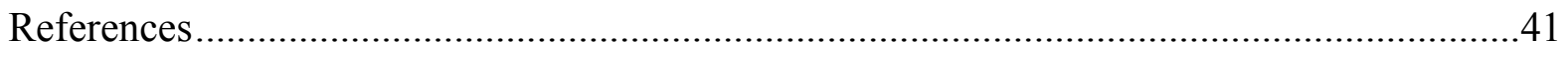


Tables

1. Mandate of the Central Bank

2. Political Independence: Appointment and Removal of Members

of the Central Bank's Board of Directors ...................................................................... 8

3. Economic Independence: Government Credit and Operational Independence ...................10

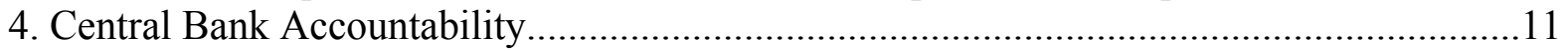

5. Legal Independence of Latin American Central Banks ................................................13

6. Latin American Economic Performance......................................................................... 15

7. Legal Central Bank Independence and Inflation in Latin America .................................. 18

8. Exchange Rate Regimes in Latin America ...............................................................19

9. Main Characteristics of Monetary Policy Operating Framework ....................................21

Figures

1. CBI and Inflation in Latin America .......................................................................... 16

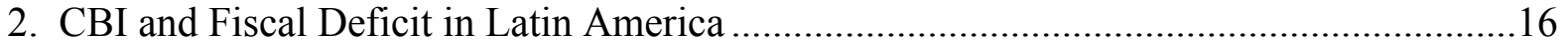

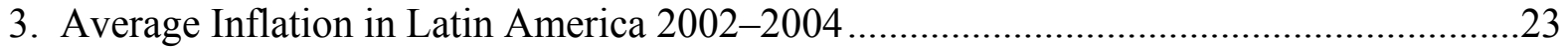

4. Transparency of Monetary Policy in Latin America ......................................................24

5. Turoner rate of Central Bank Governors .....................................................................25

6. Financial Dollarization and Inflation in Selected Latin American Countries....................29

7. Real Interest Rates in Selected Latin American Countries .............................................30

8. Response to Capital Inflows in Selected Latin American Countries ................................33

9. Real Exchange Rate in Latin America and Subregions .................................................35

10. Effects of Banking Crises on Growth and Inflation in Latin America ............................36

11. Fiscal Deficit in Selected Latin American Countries (moving average $t=3$ )...................38 


\section{INTRODUCTION}

In 1990, average inflation in Latin America reached an unprecedented high of nearly 500 percent. Three of the largest countries in the region (Argentina, Brazil, and Peru) posted quadruple-digit inflation rates, and no country managed to achieve a single-digit rate. In contrast, by that time, industrial countries had already lowered inflation to an average of approximately 4 percent, while Asian countries had brought it down on average to 6 percent. At the same time, 1990 marked the end of a 10-year period in which per capita GDP in Latin America fell on average 0.1 percent annually. With standards of living in decline, the region's governments faced the need to tackle inflation and made structural changes aimed at laying the foundations for a rebound in economic growth. ${ }^{2}$

Thus, central bank reform became, during the 1990s, a key component of the new economic agenda in most Latin American countries. The objective of the reform was to restore confidence in monetary policy and thereby wage a successful war on inflation. To ensure the credibility of the reforms, Latin American governments decided to implement the institutional changes in a highly visible way, by passing special laws and, in some cases, by amending the national constitution. As a result, up to now new central bank legislation has been enacted - in some cases more than once-in every country but Brazil. ${ }^{3}$ Reforms of the central banks led to significant institutional strengthening and to changes in the design and execution of monetary policy in a majority of countries in the region.

As a result of the reforms, Latin American central banks became more independent from their governments - to a greater degree in some countries than in others. The new legislation gave the central banks operational independence and prohibited their financing of the fiscal deficit, or at least severely restricted their ability to do so. With monetary policy independently managed, governments' chances of having potential expansionary policies associated with a country's political-business-cycle were markedly reduced. In exchange for

${ }^{2}$ Edwards (1995) provides a detailed discussion of the nature of structural reforms in Latin America, while Lora (2001) gives quantitative data on the progress achieved in each country since the mid-1980s on implementing reforms, which illustrates how the process has developed over time and how different countries compare to one another.

${ }^{3}$ Central bank reform was undertaken in Chile (1989), El Salvador (1991), Argentina (1992 and 2002), Colombia (1992), Nicaragua (1992 and 1999), Venezuela (1992, 1999, and 2002), Ecuador (1992 and 1998), Peru (1993), Mexico (1993), Bolivia (1995), Costa Rica (1995), Uruguay (1995), Paraguay (1995), Honduras (1996 and 2004), Guatemala (2001), and the Dominican Republic (2002). Although Brazil did not pass legislation to bring about reforms, it pursued social consensus in favor of the operational independence of the central bank and passed a Fiscal Responsibility Law, which strengthen the central bank's financial autonomy and accountability. Ecuador and El Salvador further reformed their central bank legislation in 2000 and 2001, respectively, but this time to adopt the U.S. dollar as legal tender. 
this autonomy, central banks were held accountable with respect to their policy actions and decisions. Within the central banks, the legal reform encouraged changes both at the policy level as well as in the operational framework for the conduct of monetary policy.

Today, most Latin American countries have guided the inflation rate to single digits, but only a handful of them are keeping pace with world inflation. Except for Costa Rica, the Dominican Republic, and Venezuela, all other countries brought inflation down to single digits by end-2004. However, only Chile and Peru, and the dollarized Panama and Ecuador have managed to make their inflation rates converge to the international rate, as measured by the level of inflation in the industrial countries.

The main objective of this paper is to examine the nature of central banks' reform in Latin America since the early 1990s, its institutional and policy implications, and the main challenges that they are facing today. Section II of the paper focuses on the key aspects of the reform of Latin American central banks and quantifies the impact of these reforms as measured by the degree of legal independence of central banks. Section III examines the impact of central bank reform on inflation - albeit without establishing causality - by considering the periods before and after the institutional changes were introduced. Section IV describes central banks' policy changes stemming from reform. Section V identifies the main challenges facing Latin America's central banks in light of recent regional developments. Finally, Section VI sets out the paper's main conclusions.

\section{The New Institutional Framework for Monetary Policy}

Latin America's central banks are relatively young institutions. Not only did they come into being more than a century after the countries achieved independence, they were established much later than their counterparts in Europe and even later than their counterpart in the United States. Except for the Banco de la República Oriental del Uruguay, which was established with the double role of central bank and commercial bank at the end of the nineteenth century, most Latin America's central banks were created in the 1920s and 1930s. ${ }^{4}$

Since central banks were established in Latin America, they have undergone various reforms, including the most recent adopted since the early 1990s. Along this period and up to the latest reform, the central bank ownership evolved from a joint public and private sector participation to one of exclusive state ownership. For a long time, central banks' government bodies maintained a mixed representation of both public and private sectors, including in the latter representatives of commercial banks and producers' associations. This governance structure was consistent with the mandate assigned to them, which primarily focused on

\footnotetext{
${ }^{4}$ The central banks of Chile, Colombia, Ecuador, Mexico, Bolivia, and Guatemala were all founded in the 1920s, whereas the central banks of Peru, Argentina, El Salvador, Costa Rica, and Venezuela were established in the 1930s. The central banks of Brazil and Uruguay as they exist today separated from other government agencies in the 1960 s.
} 
financing key sectors of the economy and promoting economic growth. The modality of formulation of monetary policy also changed, as governments started to play a larger role around the 1950s, using central banks to foster economic development. Thus, the instruments of monetary policy - such as credit regulation by economic activity and interest rates control-were aligned with the governments' role of promoting economic activity and growth. As a result, until the 1990s, central banks did not operate independently from policymakers and therefore central banks lacked the independence to formulate and execute monetary and exchange rate policy, with price stability being, at most, a secondary objective.

\section{A. The Institutional Reform since the Early 1990s}

In the 1990s, the legislation governing Latin America's central banks was extensively amended to make them more independent from the countries' executive branch. ${ }^{5}$ The reform implied an institutional strengthening of central banks, based on four main pillars: (i) defining a clear mandate for central banks, which places priority on maintaining price stability; (ii) giving central banks political independence to design monetary policy; (iii) granting central banks operational autonomy to execute monetary policy; and (iv) making central banks accountable. ${ }^{6}$ The main features of the reform of monetary legislation in Latin America are discussed below, including the applicable constitutional provisions - except for Ecuador and El Salvador, where the central banks play no role in monetary policy following the adoption of the U.S. dollar as legal tender.

\section{Central banks' objective}

Today, all central bank laws in the region establish that the purpose of the central bank is to ensure currency stability or price stability. In some cases, however, central banks are given other objectives as well, not always with priorities being set among them (see Table 1). The multiplicity of objectives creates potential conflicts of policy. This is the situation in Brazil, where, de jure, the central bank is also responsible for fostering or creating conditions conducive to growth and economic development. ${ }^{7}$ While the latter is a broad objective, the

${ }^{5}$ The theoretical underpinnings of this reform - implemented in industrial and developing countries alike - are derived from the work of Kydland and Prescott (1977) and Barro and Gordon (1983), who showed that, when faced with a choice between higher inflation and lower unemployment, governments generally favored higher inflation. The institutional reform was, in a great extent, inspired in Rogoff's notion (Rogoff, 1985) of turning over monetary policy to a "conservative central banker," with the aim of reducing the so-called "inflation bias."

${ }^{6}$ The main characteristics of central bank legislation in Latin America are summarized in Jácome (2003).

${ }^{7}$ De facto, this potential policy conflict has not been relevant, in particular since the issue of the inflation targeting decree in 1999. 
legal mandate of the central bank may give rise to differing interpretations when it comes to formulate monetary policy. In addition, the double mandate of maintaining price and financial system stability, with no indication of priority, may place the central bank in a situation where it faces potential conflicting objectives, in particular, during periods of banking system stress. ${ }^{8}$ Beyond these potential policy conflicts, having multiple objectives makes more difficult to assess the accountability of central banks.

Table 1. Mandate of the Central Bank

\begin{tabular}{|l|l|l|l|}
\hline \multirow{2}{*}{$\begin{array}{l}\text { Price stability as the sole } \\
\text { or primary objective }\end{array}$} & \multicolumn{3}{|c|}{ Price stability plus other objectives, with no indication of priority } \\
\cline { 2 - 4 } & $\begin{array}{l}\text { Operation of the payment } \\
\text { system }\end{array}$ & $\begin{array}{l}\text { Stability of the financial } \\
\text { system }\end{array}$ & $\begin{array}{l}\text { Growth or economic } \\
\text { development }\end{array}$ \\
\hline $\begin{array}{l}\text { Argentina, Bolivia, } \\
\text { Colombia, Costa Rica, } \\
\begin{array}{l}\text { Dominican Republic, } \\
\text { Mexico, Peru, Venezuela }\end{array}\end{array}$ & $\begin{array}{l}\text { Chile, Honduras, } \\
\text { Nicaragua }\end{array}$ & $\begin{array}{l}\text { Guatemala, Paraguay, } \\
\text { Uruguay }\end{array}$ & Brazil \\
\hline
\end{tabular}

Source: Latin American national constitutions and central bank legislation as of 2003.

\section{Political independence}

Following the institutional reform, Latin American central banks are more independent from governments. As observed in Table 2, today central banks' boards of directors are appointed for a tenure that exceeds or overlaps with the country's constitutional term, rarely including private sector representatives or from other public sector entities. In addition, the law requires in many countries that the Congress confirm these appointments or, in some cases, to appoint them following executive branch nominations. ${ }^{9}$ As a key feature of political independence, in many countries the new legislation specifies legal grounds for removing members of the central bank board of directors and places the final decision in the hands of the legislative or the judicial branch. ${ }^{10}$ In severing the link between the central bank and the

${ }^{8}$ Although in countries like Argentina, Brazil, Paraguay, and Uruguay the central bank performs the dual role of formulating and conducting monetary policy and supervising and regulating banks, the conventional wisdom claims that the objective of maintaining the stability of the financial system should be subordinated to the objective of maintaining price stability as it is established by law in Argentina.

${ }^{9}$ In several countries, the law establishes different provisions with respect to the central bank's governor and its executive board. In those cases, the governor is typically appointed or removed by the executive branch, while members of the executive board are appointed or removed by the legislative branch.

${ }^{10}$ Yet, in a number of cases, the legislation establishes grounds for removal of central bank governors and members of the board, which relate to policy decisions. Guatemala is a case in 


\section{Operational independence}

The provision of instruments independence for the conduct of monetary policy is probably the most common feature of the central bank reform in Latin America. This implies that central banks have today freedom to formulate and execute monetary policy. ${ }^{11}$ To strengthen this operational autonomy, central banks are severely restricted, and in some cases prohibited, of financing public expenditure (see Table 3 ). ${ }^{12}$ The prohibition of monetizing the fiscal deficit reflects the consensus achieved in the region that financing the fiscal deficit has historically been the main cause of the chronic inflation that afflicted the region.

Operational independence also implies that central banks are empowered to manage their own interest rates, thereby influencing commercial banks' interest rates, and those of other financial instruments. ${ }^{13}$ Nonetheless, operational independence is some times undermined as a result of central banks' quasi-fiscal losses - those arising from the discharge of their functions. Given that in most countries in Latin America governments are not required to make up for central bank losses, or there is no statutory requirement for recapitalization if reported capital drops below zero (see Table 3), persistent large losses may reduce the operating independence of central banks and eventually may curtail the effectiveness of monetary policy actions. The accumulation of central bank losses may limit either their capacity to mop up excess liquidity or their ability to raise interest rates when conducting open-market-operations, as they become an undesirable source of monetization that will require subsequent efforts of sterilization. In the event that operating losses become a perennial distortion, like in a number of central banks in the region, markets may cast doubts about central banks' long-term ability to preserve price stability.

\footnotetext{
${ }^{11}$ In some countries (Mexico and Venezuela, for instance), the government has retained the power to co-participate in the formulation of exchange rate policy, which has the potential for interfering operational independence. However, this potential restriction is non-binding in countries with flexible exchange rate regimes.

${ }^{12}$ Nonetheless, the spirit of this restriction has been violated based on alternative legal grounds. A case in point is Venezuela, where the central bank law requires the central bank to transfer to the government unrealized profits associated to the revaluation of international reserves. Another violation occurs in countries where the annual budget approved by law in Congress requires central banks to make transferences to the government, like in Honduras and Paraguay, for example.

${ }^{13}$ Exactly how interest rates respond to actions taken by the central bank depends essentially on what impact the latter have on inflationary expectations. Changes in interest rates and expectations, in turn, affect aggregate supply and demand, and hence, economic activity and inflation.
} 
Table 3. Operational Economic Independence

\begin{tabular}{|c|c|c|}
\hline \multicolumn{3}{|c|}{ Credit to the Government by the Central Bank } \\
\hline $\begin{array}{l}\text { No direct or indirect credit, or } \\
\text { credit extended on the secondary } \\
\text { market with limits }\end{array}$ & $\begin{array}{l}\text { Credit to cope with seasonal } \\
\text { liquidity shortages, or credit } \\
\text { extended on the secondary market } \\
\text { without limits }\end{array}$ & Direct credit \\
\hline $\begin{array}{l}\text { Argentina, Chile, Costa Rica, } \\
\text { Brazil, Dominican Republic, } \\
\text { Guatemala, Peru, Uruguay, } \\
\text { Venezuela }\end{array}$ & $\begin{array}{l}\text { Bolivia, Honduras, Mexico, } \\
\text { Nicaragua, Paraguay }\end{array}$ & Colombia \\
\hline \multicolumn{3}{|c|}{ Independence in the Use of Monetary Policy Instruments } \\
\hline $\begin{array}{l}\text { Full independence in monetary and } \\
\text { exchange rate policy }\end{array}$ & $\begin{array}{l}\text { Restrictions on the conduct of } \\
\text { monetary or exchange rate policy }\end{array}$ & $\begin{array}{l}\text { Monetary and exchange rate policy } \\
\text { set by the government }\end{array}$ \\
\hline $\begin{array}{l}\text { Argentina, Bolivia, Brazil, Chile, } \\
\text { Colombia, Costa Rica, Dominican } \\
\text { Republic, Honduras, Nicaragua, } \\
\text { Peru, Uruguay }\end{array}$ & $\begin{array}{l}\text { Guatemala, Mexico, Paraguay, } \\
\text { Venezuela }\end{array}$ & \\
\hline \multicolumn{3}{|c|}{ Financial Independence } \\
\hline $\begin{array}{l}\text { Government is required to maintain } \\
\text { central bank's capital }\end{array}$ & $\begin{array}{l}\text { Government is authorized but is } \\
\text { not required to capitalize the } \\
\text { central bank, or capitalizes it with } \\
\text { nonnegotiable bonds }\end{array}$ & $\begin{array}{l}\text { No legal basis exists for the } \\
\text { government capitalizing the central } \\
\text { bank }\end{array}$ \\
\hline $\begin{array}{l}\text { Brazil, Colombia, Dominican } \\
\text { Republic, Guatemala, Nicaragua, } \\
\text { Peru, Venezuela }\end{array}$ & Bolivia, Chile, Mexico & $\begin{array}{l}\text { Argentina, Costa Rica, Honduras, } \\
\text { Paraguay, Uruguay }\end{array}$ \\
\hline $\begin{array}{l}\text { Source: Latin American national } \\
\text { Responsibility Law in Brazil. }\end{array}$ & stitutions and central bank legis & as of 2003, and Fiscal \\
\hline
\end{tabular}

There are other situations where central banks' autonomy to conduct monetary policy is restricted. An undesirable situation is that of Guatemala, where the national Congress approves the issue of central bank paper for open-market-operations purposes, a situation that may inhibit the conduct of monetary policy. In addition, there are central banks that do not have financial independence as Congress approves their budget, and therefore, they may lack the necessary resources to accomplish their responsibilities (like in Honduras and Paraguay).

\section{Accountability}

Accountability requirements are an innovating feature of the legislation governing most central banks in Latin America (see Table 4). The purpose of this reform was to hold central 
Table 4. Central Bank Accountability

\begin{tabular}{|l|l|l|}
\hline \multicolumn{3}{|c|}{ Reporting by the Central Bank } \\
\hline Formal appearance before the legislature & $\begin{array}{l}\text { Submission of a report to the executive or legislative } \\
\text { branch, or publication of a report in the news media }\end{array}$ \\
\hline $\begin{array}{l}\text { Argentina, Brazil, Chile, Colombia, Dominican } \\
\text { Republic, Guatemala, Mexico, Paraguay, Venezuela }\end{array}$ & $\begin{array}{l}\text { Bolivia, Costa Rica, Honduras, Nicaragua, Peru, } \\
\text { Uruguay, Mexico }\end{array}$ \\
\hline \multicolumn{3}{|c|}{ Publication and Transparency of Information } \\
\hline $\begin{array}{l}\text { Financial statements certified by } \\
\text { external auditors }\end{array}$ & $\begin{array}{l}\text { Financial statements certified by a } \\
\text { public agency separated from the } \\
\text { central bank }\end{array}$ & $\begin{array}{l}\text { Financial statements signed by an } \\
\text { auditor appointed by the central } \\
\text { bank's executive board }\end{array}$ \\
\hline $\begin{array}{l}\text { Argentina, Chile, Guatemala, } \\
\text { Mexico, Nicaragua }\end{array}$ & $\begin{array}{l}\text { Brazil, Colombia, Honduras, } \\
\text { Paraguay, Uruguay, Venezuela }\end{array}$ & $\begin{array}{l}\text { Bolivia, Costa Rica, Dominican } \\
\text { Republic, Peru }\end{array}$ \\
\hline \multicolumn{3}{|l|}{$\begin{array}{l}\text { Source: Latin American national constitutions and central bank legislation as of 2003, and Fiscal } \\
\text { Responsibility Law in Brazil. }\end{array}$} \\
\hline
\end{tabular}

banks accountable in exchange for the substantial independence they were granted. Until the reform, central banks in the region typically published an annual report describing the overall economic performance of the countries, which served essentially as an historical record and not as an accountability procedure. Following the reforms of the 1990s, central bank governors in a number of countries are required to appear before the legislature to report on the conduct of monetary policies and the performance in pursuing their objective of preserving price stability. In addition, central banks publish regularly its monetary program for the foreseeable future, in a number of cases, together with an inflation report that assesses central banks' actions aimed at achieving the inflation targets.

A critical component of central banks' accountability is the transparency of financial transactions. In this regard, Table 4 shows that there is room for improvement in a number of central banks in the region. While practically all central banks disclose their financial statements on a regular basis, best practices advice that central banks disclose them certified by an external audit firm, which verify that central banks' transactions have been properly recorded in accordance with international accounting standards. In fact, a number of central banks in the region do not account properly operational losses and eventually they hide negative capital positions.

\section{B. How Independent Are Central Banks in Latin America?}

Latin American central banks enjoy greater independence today than they did before the reforms. To reach this conclusion, we use an expanded and slightly modified version of the Cukierman index (Cukierman, 1992) as a quantitative criterion to gauge the institutional 
impact of the reforms. ${ }^{14}$ We calculate an index of legal central bank independence (CBI) for the old and new legislation governing central banks to ascertain how legal independence has evolved over time. The CBI index also allows us to compare the legal independence of central banks across countries.

The index of CBI was estimated based on the provisions contained in the central bank legislation and the relevant parts of national constitutions and applied to the 15 countries in the region referred to in section II.A. ${ }^{15}$ Thus, it does not measure the central banks' effective independence. The difference between de jure and de facto independence is relevant, in particular in countries where institutions are weak, where a good central bank law may not be observed in practice. The high rate of turnover of central bank governors in most countries in the region (see section V.A) can illustrate the lack of effective central bank independence in Latin America, since in many cases it reflects an early dismissal of central bank governors when their actions were at odds with government policies. In contrast, there are countries in which the central bank legislation is rather poor but the government values the institutional role and decisions of the central bank, as witnessed for example in Brazil during the last ten years.

The index of CBI is built on five different aspects of central bank independence, which are assigned different weights in the spirit of Cukierman (1992). The resulting value of the CBI gives a score between zero and one. The first aspect measures political independence of the central bank by assessing the modality of appointment of central banks' board of directors, the length of their tenure - relative to the term of the executive branch - and the legal provisions for their removal ( 20 percent). The second relates to the nature of the central bank's mandate, assigning high marks to those central banks that pursue primarily the objective of preserving price stability (15 percent). The third aspect relates to the autonomy of central banks in the formulation of monetary policy (15 percent). The fourth criterion assesses central bank's restrictions in lending provisions to the government and to commercial banks as a lender of last resort, as well as its financial independence 40 percent). The fifth one evaluates central banks' accountability requirements $(10$ percent $){ }^{16}$

Latin American central banks are considerably more independent today than they were in 1990, although the degree of independence varies from one country to another. The average modified Cukierman index increased from 0.427 to 0.774 in the wake of the institutional

\footnotetext{
${ }^{14}$ The differences between the Cukierman index and the modified index used in this paper are described in Jácome and Vázquez (2005).

${ }^{15}$ In the case of Brazil, the legal framework also included the relevant provisions in the Fiscal Responsibility Law approved in 2000, which strengthen financial independence and accountability of the Central Bank of Brazil.

${ }^{16}$ Jácome and Vázquez (2005) discuss the specifics of this index.
} 
reform. On the other hand, current independence is not uniform across countries in the region. Table 5 identifies two groups of countries. Group 1 encompasses those countries where central banks became more independent, which have a CBI index of over 0.80 (Peru, Chile, Bolivia, Colombia, Mexico, and the Dominican Republic). The remaining countries, Group 2, have less independent central banks as the CBI index is in the range of 0.65 to 0.79 . There is also a third group, which includes all countries prior to the reform of their central bank legislation, whose CBI is below 0.60 and mostly smaller than 0.50 , except for Brazil.

Table 5. Legal Independence of Latin American Central Banks (Modified Cukierman index, end-2003)

\begin{tabular}{|c|c|c|c|c|c|}
\hline Group 1 & CBI & Group 2 & CBI & Group 3 & CBI \\
\hline Peru-1 & 0.862 & Argentina-1 & 0.788 & Brazil */ & 0.641 \\
\hline Chile-1 & 0.846 & Venezuela-1 & 0.750 & Nicaragua- 0 & 0.590 \\
\hline Colombia-1 & 0.827 & Costa Rica-1 & 0.739 & Guatemala-0 & 0.565 \\
\hline Bolivia-1 & 0.825 & Nicaragua-1 & 0.733 & Costa Rica-0 & 0.510 \\
\hline Mexico-1 & 0.805 & Paraguay-1 & 0.702 & Peru-0 & 0.502 \\
\hline \multirow[t]{10}{*}{ Dominican Republic-1 } & 0.805 & Guatemala-1 & 0.690 & Dominican Republic -0 & 0.435 \\
\hline & & Honduras-1 & 0.682 & Uruguay -0 & 0.435 \\
\hline & & Uruguay-1 & 0.669 & Venezuela-0 & 0.395 \\
\hline & & & & Mexico-0 & 0.388 \\
\hline & & & & Honduras -0 & 0.385 \\
\hline & & & & Paraguay-0 & 0.368 \\
\hline & & & & Bolivia-0 & 0.326 \\
\hline & & & & Argentina -0 & 0.314 \\
\hline & & & & Colombia-0 & 0.289 \\
\hline & & & & Chile- 0 & 0.263 \\
\hline Average - Group 1 & 0.828 & Average - Group 2 & 0.719 & Average - Group 3 & 0.427 \\
\hline \multicolumn{6}{|c|}{$\begin{array}{l}\text { */ Incorporates provisions from the Fiscal Responsibility Law (2000) and a Constitutional } \\
\text { amendment (2003) that strengthens the central bank's independence. } \\
\text { Note: Country-1 refers to the measurement subsequent to the reforms, while Country- } 0 \text { refers to the } \\
\text { measurement prior to the reforms. }\end{array}$} \\
\hline
\end{tabular}

Breaking down the CBI index into political independence, economic independence, and accountability, we conclude that the increase in independence was not uniform with respect to all three criteria. While the differences vis-à-vis Group 3 are evident in all three criteria, the difference between Groups 1 and 2 is found primarily in terms of political independence - appointment and removal of central banks' board of directors and central banks' mandate - and to less extent in terms of accountability. In turn, operational independence, including the autonomy to formulate monetary policy, is virtually uniform in all countries that reformed their central bank legislation. 


\section{Legal Central Bank IndePendence AND MaCroeconomic Trends IN LATIN AMERICA}

Latin America has improved its macroeconomic performance from 1990 onward, although the results are below the initial expectations. Without question, the greatest achievement has been to bring inflation down to single-digit levels. This section reviews briefly major macroeconomic developments and stresses the contribution of CBI to disinflation. To characterize CBI, we use the modified Cukierman index and apply it to the period preceding the reform in each country and to the subsequent years up to 2003.

\section{A. A Brief Tour on the Macroeconomic Performance Following the Reform}

Although the macroeconomic results achieved in Latin America do not fully meet the expectations raised at the time the reforms were instituted, there was indeed an improvement in comparison with the previous decade. ${ }^{17}$ The progress is particularly striking concerning inflation as it plunged to single-digit rates despite the deleterious effects of successive real and financial shocks that hit the region since mid-1990s onward.

Table 6 reviews the macroeconomic performance of Latin America during the period 1980 to 2003 divided into three subperiods. First, the 1980s, before the reform of central banks materialized. Second, the first half of the 1990s, when most economies in the region reformed their central bank legislation and other structural reforms were enacted. And third, from 1996 onwards, when most countries in the region had completed the reform of their central bank legislation. For each subperiod, macroeconomic indicators are weighted according to the country's relative GDP.

Latin America reversed the economic downturn of the 1980s but only achieved a per-capita GDP growth of less than 1 percent. The slight deceleration in economic growth that took place during the recent period largely reflects the impact of financial crises that hit a number of countries from mid-1990s onward. México and Venezuela in the mid-1990s and Argentina, the Dominican Republic, Ecuador, Nicaragua, Paraguay, and Uruguay towards the late 1990s and early 2000s are cases in point.

The external and fiscal performance of the region featured mixed results. The pace of growth in the volume of exports accelerated and the current account deficit remained on check-at less than 3 percent of GDP. However, the fiscal deficit has picked up recently following the drastic reduction achieved in the first half of the 1990s, and the public external debt remains high despite its reduction following debt restructurings negotiated during the late-1980s and early 1990s. ${ }^{18}$ The deterioration of public finances also reflects the adverse effects of banking

${ }^{17}$ This analysis looks at all the countries in the region, including the Caribbean countries.

${ }^{18}$ The fiscal deficit in this case corresponds only to the central government data alone rather than using information from the non-financial public sector. 
and currency crises, which in a few cases also turned into a simultaneous sovereign debt crises - like those in Ecuador, Argentina, and Uruguay.

Table 6. Latin American Economic Performance (1980-2003. In percentages)

\begin{tabular}{lccc}
\hline & $1980-1989$ & $1990-1995$ & $1996-2003$ \\
\hline Per capita real GDP growth & -0.14 & 0.89 & 0.85 \\
Inflation rate (period average) & 149.19 & 227.85 & 9.93 \\
Exports (volume growth rate) & 8.01 & 8.24 & 8.99 \\
Current account / GDP & -2.21 & -2.20 & -2.44 \\
Fiscal balance / GDP & -3.79 & -0.68 & -2.63 \\
External Public Debt / GDP & 46.86 & 38.44 & 40.09 \\
\hline
\end{tabular}

Source: Western Hemisphere Department, International Monetary Fund.

1/ Includes the Caribbean countries.

\section{B. Has CBI Played Any Role in Reducing Inflation in Latin America?}

As opposed to other regions, the contribution of CBI towards reducing inflation in Latin America has received little attention in the literature. A recent paper by Jácome and Vázquez (2005) finds that CBI is statistically significant in explaining inflation performance between 1990 and 2002 for the Latin American and Caribbean economies. The analysis incorporates the periods before and after central bank reforms, and controls for other macroeconomic variables and for a broad index of structural reform that excludes the monetary reform. ${ }^{19}$ This section highlights the salient aspects of the correlation between the CBI index and inflation for Latin American countries albeit without establishing causality from CBI to inflation.

As a first approximation, Figures 1 to 2 show the relationship between the CBI index and both inflation and the fiscal deficit, before and after the monetary reform. The pre-reform period covers the five years prior to the reform of the central bank in each country, including

\footnotetext{
${ }^{19}$ Studies using samples that include developed countries and economies in transition reach a similar conclusion. For studies that look at developed countries, see for example the seminal works by Grilli, Masciandaro, and Tabellini (1991) and Cukierman (1992), as well as the study by Eijffinger and Schaling (1993) and the more recent studies by Eijffinger, Schaling, and Hoeberichts (1998), and Brumm (2000). For studies that look at economies in transition, see for example Loungani and Sheets (1997) and Cukierman, Miller, and Neyapti (2002).
} 
the year in which legal changes materialized, while the post-reform period goes up to 2003. For each period, averages for inflation and for the nonfinancial public sector deficit were calculated and compared with the pre-reform and post-reform CBI indices. ${ }^{20}$

Figure 1. $\mathrm{CBI}$ and Inflation in Latin America

(Before and after the reform of central banks)

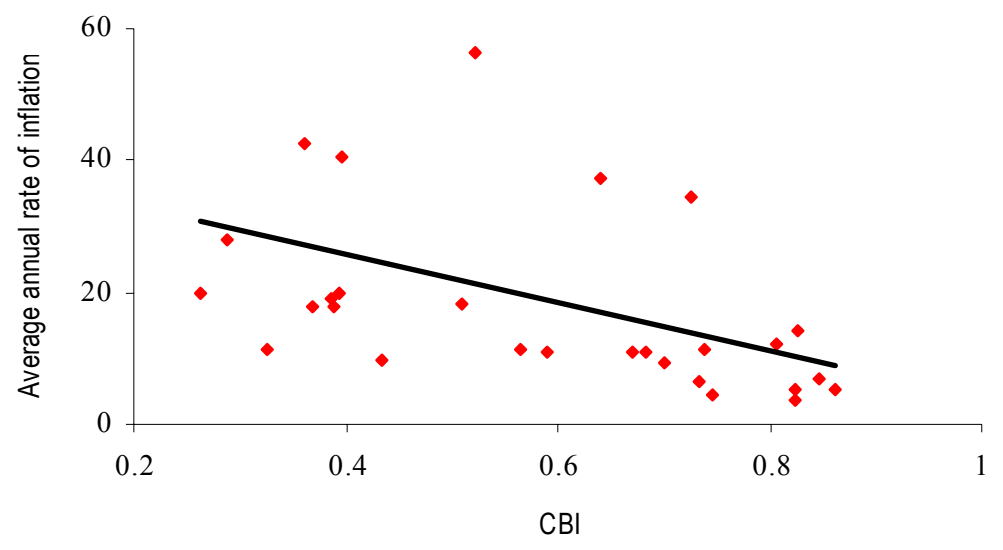

Figure 2. $\mathrm{CBI}$ and Fiscal Deficit in Latin America

(Before and after the reform of central banks)

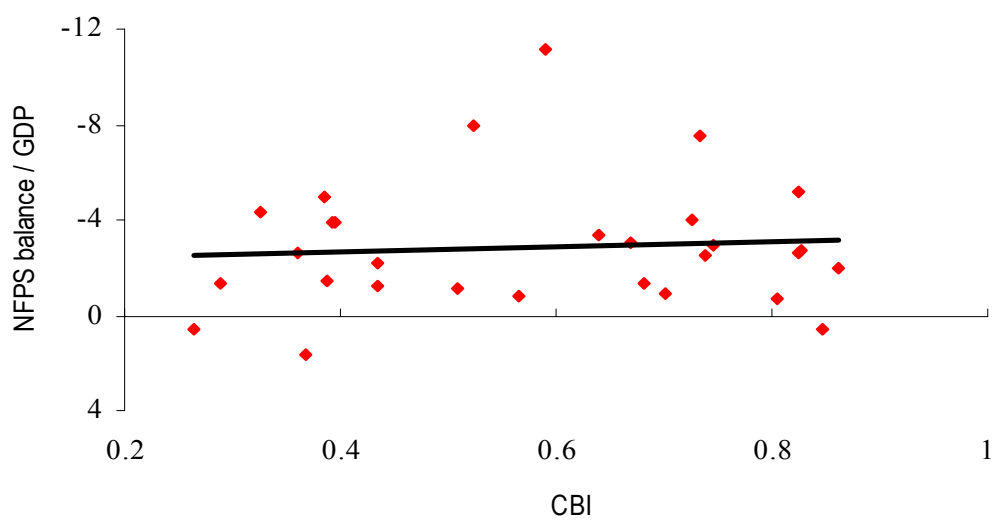

${ }^{20}$ Exceptionally, the post-reform period considered for Ecuador goes up only to 1999 and for El Salvador only to 2000, when those two countries adopted the U.S. dollar as legal tender. 
The negative correlation between inflation and the CBI index in Latin America is statistically confirmed. The analysis is conducted lagging the CBI index with respect to the year of approval of the institutional reform of monetary policy in each country. The purpose of lagging this variable is to capture a learning process associated to the implementation of the new monetary policy framework and the development of the expertise required to operate under the new institutional framework. In addition, the lags make room for a process of building credibility, which is a necessary asset that central banks require to reduce inflation. The regression also includes two dummy variables to control for other potential influences in price formation and to limit the adverse statistical effect of a missing variables problem. The first dummy variable seeks to isolate the effect on inflation of systemic banking crises. ${ }^{21}$ In turn, the second dummy variable is intended to capture the influence on disinflation from fixed and hard-peg exchange rate regimes - measured on the basis of a de facto criterion, according to the IMF's classification of countries' exchange rate regimes. In addition, the analysis controls for world inflation (measured in terms of the average inflation in the G-7 countries) to take into account the potential influence of external inflation in the disinflation process in Latin America. Likewise, an index of structural reform is included as an independent variable, which may have contributed to reduce rigidities in price formation. ${ }^{22}$ Table 7 reports the results of the regression using panel data for the 17 Latin American countries considered in the preceding section for the period from 1990 to 2002, and hence, including the pre-reform and post-reform periods. ${ }^{23}$ The coefficients of all variables have the expected sign and are statistically significant at least at 5 percent. In particular, the level of significance of the coefficient of the variable CBI improves as the time lag increases to three and four periods, which is consistent with the idea that central banks gain ability to defeat inflation as they build credibility and achieve expertise in the conduct of monetary policy.

\section{Changes in the Policy Regime and Innovations in the Operating Framework of Monetary Policy}

The reform of central bank legislation in Latin America contributed to the change in the monetary policy regime and the operating framework observed in most countries of the region. Following the reform, most central banks increasingly migrated from exchange rate

\footnotetext{
${ }^{21}$ For this dummy variable, a value of 1 is assigned in the years when a systemic banking crisis occurred and 0 elsewhere.

${ }^{22}$ This variable takes a value in the range of 0 to 1 , with higher variables reflecting deeper structural reforms. The data is obtained from the structural reform index calculated for Latin America by the Inter-American Development Bank. The index incorporates reforms in the trade, tax, financial, and labor spheres, and also includes privatization (see Lora, 2001).

${ }^{23}$ The specifics of the methodology used in this statistical exercise are similar to those discussed in Jácome and Vázquez (2005) for a sample that also includes the Caribbean countries.
} 
Table 7. Legal Central Bank Independence and Inflation in Latin America (Panel regressions of inflation on lagged CBI data)

Dependent variable: inflation scaled as $\pi /(1+\pi)$

\begin{tabular}{|l|c|c|c|c|}
\hline \multicolumn{1}{|c|}{ Explanatory variables } & Lagged & Lagged & Lagged & Lagged \\
& 1 Period & 2 Periods & 3 Periods & 4 Periods \\
\hline Dummy variable for banking crises & $0.041^{* *}$ & $0.044^{* *}$ & $0.041^{* *}$ & $0.041^{* * *}$ \\
& $(0.017)$ & $(0.019)$ & $(0.020)$ & $(0.021)$ \\
\hline Dummy variable for exchange rate regime & $-0.052^{* *}$ & $-0.049^{* * *}$ & $-0.058^{* * *}$ & $-0.068^{* * *}$ \\
& $(0.021)$ & $(0.018)$ & $(.009)$ & $(0.009)$ \\
\hline World inflation & $0.037^{* * *}$ & $0.027^{* * *}$ & $0.024^{* * *}$ & $0.025^{* * *}$ \\
& $(0.007)$ & $(0.009)$ & $(0.008)$ & $(0.009)$ \\
\hline Structural reform index & $-0.392^{* * *}$ & $-0.284^{* * *}$ & $-0.364^{* * *}$ & $-0.449^{* * *}$ \\
& $(0.117)$ & $(0.109)$ & $(0.089)$ & $(0.083)$ \\
\hline CBI index (modified Cukierman index) & -0.020 & -0.037 & $-0.065^{* * *}$ & $-0.042^{* *}$ \\
& $(0.029)$ & $(0.028)$ & $(0.021)$ & $(0.020)$ \\
\hline Number of observations & 158 & 147 & 133 & 117 \\
\hline Number of countries & 17 & 17 & 17 & 17 \\
\hline Rho & 0.56 & 0.50 & 0.40 & 0.33 \\
\hline
\end{tabular}

Standard errors in parentheses.

* Significant at 10 percent, ** Significant at 5 percent, *** Significant at 1 percent.

The coefficients were estimated using Feasible Generalized Least Squares, allowing for heteroscedasticity across countries and an AR(1) autocorrelation structure within countries, with a (Rho) coefficient common to all countries. Dummy Banking Crises equals 1 during years with banking crises and 0 elsewhere. Dummy Exchange Rate Regime equals 1 during periods of fixed exchange regimes and 0 elsewhere. World inflation is measured by the average inflation of industrial countries (IFS series 110), and the index of structural reforms varies in the interval $[0,1]$ with higher values indicating deeper economic reforms.

pegs towards exchange rate flexibility. However, instead of adopting a monetary anchor, a number of central banks adopted an inflation targeting (IT) strategy as a way of anchoring inflation expectations. At the same time, these central banks modernized their operating framework for monetary policy, shifting from the traditional modality of controlling money base as an intermediate target to an alternative regime where the central bank typically uses a short-run interest rate as an operational variable.

\section{A. Changes in the Monetary Policy Regime}

Throughout the 1990s, most Latin American countries made changes to their monetary policy regime. At the beginning of the decade, with the region having in average a triple-digit inflation rate, most countries embarked on stabilization strategies based on a nominal exchange rate anchor, usually based on regimes involving exchange rate bands and supported by growing capital inflows into the region. According to the classification in Table 8, in 1990 seven of the 18 countries in the region had a flexible exchange rate, while by 1995 there were only five. All other countries had a fixed or "super-fixed" peg, or some intermediate arrangement (typically crawling pegs or horizontal and crawling bands), which in terms of expectations worked as if they were fixed pegs. Thus, in an environment of high capital mobility and fixed exchange rates, the majority of Latin American central banks had, at least in part, given up their ability to conduct monetary policy. 
Table 8. Exchange Rate Regimes in Latin America

(De facto classification)

\begin{tabular}{|c|c|c|c|}
\hline & $\begin{array}{l}\text { Fixed exchange rate } \\
\text { or "hard peg"* }\end{array}$ & Intermediate regimes** & Floating exchange rates $* * *$ \\
\hline 1990 & $\begin{array}{l}\text { Dominican Republic, Honduras, } \\
\text { Panama }\end{array}$ & $\begin{array}{l}\text { Bolivia, Chile, Colombia, Costa } \\
\text { Rica, Ecuador, Mexico, Nicaragua, } \\
\text { Uruguay }\end{array}$ & $\begin{array}{l}\text { Argentina, Brazil, El Salvador, } \\
\text { Guatemala, Paraguay, Peru, } \\
\text { Venezuela }\end{array}$ \\
\hline 1995 & $\begin{array}{l}\text { Argentina, El Salvador, } \\
\text { Panama, Venezuela }\end{array}$ & $\begin{array}{l}\text { Bolivia, Brazil, Chile, Colombia, } \\
\text { Costa Rica, Ecuador, Honduras, } \\
\text { Nicaragua, Uruguay }\end{array}$ & $\begin{array}{l}\text { Dominican Republic, Guatemala, } \\
\text { Mexico, Paraguay, Peru }\end{array}$ \\
\hline 2003 & $\begin{array}{l}\text { El Salvador, Ecuador, Panama, } \\
\text { Venezuela }\end{array}$ & $\begin{array}{l}\text { Bolivia, Costa Rica, Honduras, } \\
\text { Nicaragua }\end{array}$ & $\begin{array}{l}\text { Argentina, Brazil, Chile, } \\
\text { Colombia, Dominican Republic, } \\
\text { Guatemala, Mexico, Paraguay, } \\
\text { Peru, Uruguay }\end{array}$ \\
\hline
\end{tabular}

Source: Bubula and Ötker-Robe (2002) and "Annual Report of Exchange Arrangements and Exchange Restrictions,"

International Monetary Fund (2003).

* Includes regimes involving formal dollarization, a monetary union, a currency board, or fixed exchange rates pegged to one currency or a basket of currencies.

** Includes regimes involving horizontal bands (forward looking and backward looking) crawling pegs, and forward looking and backward looking crawling bands.

*** Includes managed float and free float regimes.

With the reinforced autonomy of central banks to formulate and execute monetary policy, flexibility gained popularity and today 10 countries have adopted a flexible exchange rate regime. In addition, the number of countries that formally dollarized has risen to three, which confirms the bipolar trend in the choice of exchange rate regimes (Fischer, 2001). A small group of countries, kept the exchange rate as the nominal anchor. This is mostly observed in the Central American countries, given their increasing integration with the U.S. economy, and due to the high degree of financial dollarization. In this environment, central banks preferred to avoid devaluations to limit their negative impact on market expectations, price formation, and the financial system's balance sheets.

While abandoning the intermediate exchange rates, many central banks did not return to monetary targeting regimes. First, central banks discarded exchange rate pegs due to their intrinsic vulnerability to exogenous shocks in a world of high capital mobility. Exchange rate pegs proved also exposed to unsustainable fiscal disequilibrium, aggravated by the fact that exiting the peg was prone to speculative attacks and eventually to currency and possible banking crises. Monetary targeting was not considered an alternative either as central banks found difficult to predict the course of monetary aggregates in the short-run, given the instability of the demand for money and the volatility of the money multiplier. As a result, central banks would find it difficult to commit to a credible economic management based on the control of a monetary variable as an intermediate policy target. 
Unfortunately, the transition to exchange rate flexibility was traumatic. It took place amid financial crises that made intermediate exchange rate regimes unsustainable (Brazil, Ecuador, Mexico, Uruguay, and Venezuela, to mention a few examples) and sparked swift and steep devaluations. Only Chile and Colombia managed to make an orderly transition, even though Colombia did it in the middle of a banking crisis.

With the change to a flexible exchange rate regime, a number of central banks gradually instituted IT schemes in the second half of the 1990s (Brazil, Chile, Colombia, Mexico, and Peru). The adoption of IT schemes did not simply mean announcing multiyear inflation targets, but implied instead the adoption of an alternative monetary policy framework. On the basis of their enhanced independence and a clearly defined policy objective, these central banks implemented transparent decision-making mechanisms and stringent accountability practices. In addition, insofar as possible, central banks adopted a monetary policy rule that was widely disclosed and explained to the market, with the aim of guiding economic agents about their policy reaction function when facing potential inflationary pressures. As a key component of the new monetary regime, IT central banks developed inflation forecasting models to predict more accurately future inflation, and hence, to better support inflation target announcements.

\section{B. The New Operational Framework}

The adoption of IT regimes contributed to the modernization of the operational framework for monetary policy in Latin America. As a result, central banks established a coherent framework based on the control of systemic banks liquidity, the use of a short-term interest rate as the principal instrument of monetary policy, and the adoption of transparent policy rules to send signals to the market about their monetary policy stance. In adopting these rules, central banks sought to enhance the effectiveness of monetary policy by facilitating the alignment of market expectations with inflation targets.

Most central banks adopted the overnight interest rate - rather than a quantity variable - as their operational or policy variable based on the criterion that overnight rates are easier to control (Table 9). ${ }^{24}$ To steer interbank interest rates close to the operational variable, central banks engage in open-market-operations using overnight repo-and reverse repooperations. In any case, because the interbank rate may be subject to volatility, most central banks that have adopted IT schemes established an interest rate corridor to mitigate such volatility. The floor of the corridor is typically the overnight rate applicable to a deposit facility, instituted to serve financial intermediaries that did not want, or were unable, to place their excess liquidity on the interbank market at the end of the day. The ceiling of the corridor is usually the rate charged by the central bank to financial intermediaries requesting overnight liquidity assistance.

${ }^{24}$ In industrialized countries there is a general trend to use the short-term interest rate as the operational variable. 
Table 9. Main Characteristics of Monetary Policy Operating Framework (Selected Latin American countries)

\begin{tabular}{lcccc}
\hline & Operational Variable & $\begin{array}{c}\text { Liquidity } \\
\text { Projection }\end{array}$ & $\begin{array}{c}\text { Interest Rate } \\
\text { Corridor }\end{array}$ & $\begin{array}{c}\text { Benchmark Rate } \\
\text { (Price or Quantity) }\end{array}$ \\
\hline Argentina & Monetary base & Daily & No & None \\
Brazil & Overnight interest rate & Daily & Yes & Interest rate \\
Chile & Overnight interest rate & Daily & Yes & Interest rate \\
Colombia & Overnight interest rate & Daily & Yes & Interest rate \\
Dominican Republic & Net domestic assets* & Weekly & Yes & None \\
Guatemala & Net domestic assets* & Weekly & No & None \\
Mexico & Bank liquidity & Daily & No & Liquidity \\
Paraguay & Net domestic assets* & No & No & None \\
Peru & Overnight interest rate & Daily & Yes & Interest rate \\
Uruguay & Monetary base (monthly & Daily & No & Monetary base \\
& average) & & & \\
\hline
\end{tabular}

* This is a de facto variable in the framework of the economic program these countries have negotiated with the IMF. Strictly speaking, it is more of an intermediate variable, in terms of traditional financial programming, rather than an operational variable.

In addition, central banks, in particular in IT countries, generally use the policy rate to signal changes in the stance of monetary policy. For instance, they increase the policy rate (the SELIC rate in Brazil, for example) when inflationary pressures strengthen and decrease it when they ease. As an exception, Mexico uses a quantity variable (the corto) with the same purpose. Typically, central bank monetary policy committees adopt these decisions during preannounced meetings.

With the adoption of an operational target, central banks seek to influence the behavior of longer-term interest rates, including those charged by financial intermediaries. In turn, central banks expect that financial systems' interest rates tend to influence aggregate demand and aggregate supply, and hence, inflation. ${ }^{25}$ In this connection, the operational target has become a key factor in the monetary policy transmission mechanism.

\section{Challenges Facing Latin America's Central Banks}

Despite the successes in defeating inflation, central banks in Latin America still face important challenges in the perspective of consolidating credibility and conquering inflation. First, Latin America's inflation has still to converge toward the world inflation-as measured through the G-7 countries' inflation rate. Second, most central banks in the region need to

${ }^{25}$ The impact on the real sector of the economy is a direct function of the development of the financial market, especially the interbank market. 
restore confidence in the domestic currency, not only as a mean of transaction, but also as a store of value. An third, central banks needs to cope with capital inflows without sacrificing the objective of attaining and preserving price stability. Overcoming these difficulties, however, is not only a central bank duty since governments also bear some responsibilities, in particular, preserving the stability of the financial system and maintaining fiscal deficits on check.

While this document provides general recommendations to cope with today's main central bank challenges, more specific proposals are needed. They should be widely analyzed in the years to come as part of the research agenda of central banks in the region and, to some extent, of the multilateral financial institutions.

\section{A. Achieve Price Stability}

While inflation in Latin America has already declined in average to single digits, in most countries it has not converged yet to the world inflation. When measuring inflation for the period 2002-2004, only one third of the countries in the region reached a rate below 4 percent, with two of those six countries having been formally dollarized. Likewise, almost one half of all countries - excluding the dollarized economies - featured a rate that exceeded 8 percent in average in the same period (see Figure 3), which is approximately the threshold

identified in the empirical literature as carrying costs in terms of economic growth. ${ }^{26}$ In 2004 , while in a number of countries inflation dropped markedly (Argentina, Brazil, Paraguay, Uruguay), in other countries, particularly in Central America, inflation picked up to about 10 percent on average at the end of the year.

Further reducing inflation should be a key goal of central banks in Latin America. However, this may be an increasingly difficult endeavor because of its potential adverse effects in output. ${ }^{27}$ While in the 1990 s governments in the region seemed to unconditionally support anti-inflation policies as a vital social objective, today this emphasis has lost momentum and, instead, governments are focusing their efforts in spurring economic growth - after three years of negative growth in per-capita GDP and three decades of very modest improvement.

${ }^{26}$ See Sarel (1996), which places the threshold at 8 percent, and the more recent work by Khan and Senhadji (2000) which, for developing countries only, places the threshold in the range of 7 to 11 percent.

${ }^{27}$ In the last ten years there has been increased attention in the industrial countries to the analysis of the negative effects on output stemming from disinflation efforts, in particular following the institutional reform that strengthened central banks independence. In this connection, Fischer (1995), Fischer (1996), and Gartner (1997) found empirical evidence of a positive correlation between central bank independence and the "sacrifice ratio."

Furthermore, Andersen and Wascher (1999) claim that the "trade-off" between inflation and growth - in industrial countries - intensifies when inflation is below 8 per cent. 
Under these conditions, central banks may face a political environment opposed to tight monetary policies.

Figure 3. Average Inflation in Latin America 2002-2004

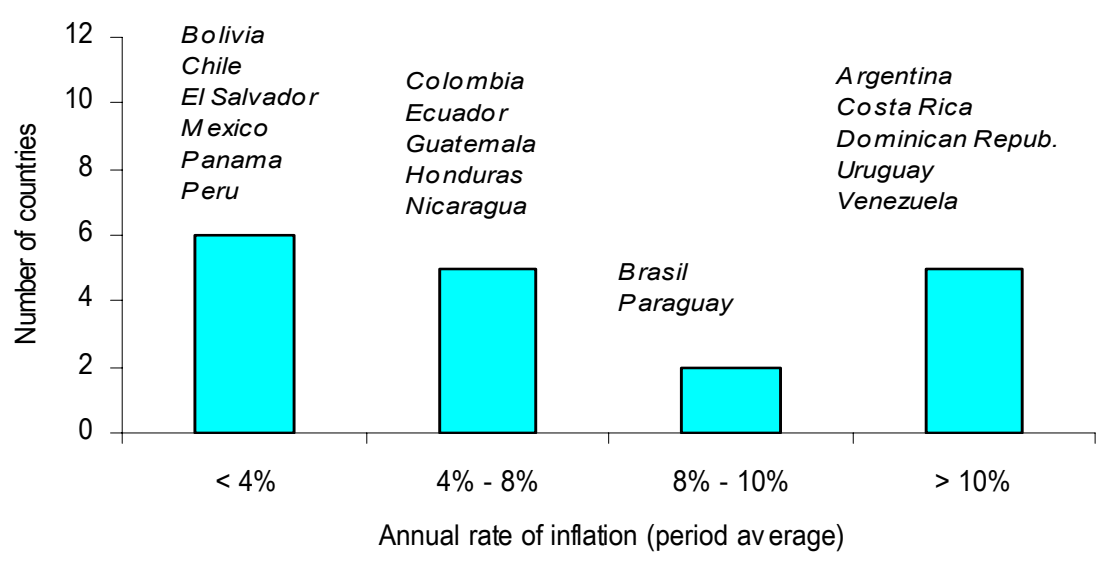

Source: International Financial Statistics, IMF.

The alternative is that central banks keep on seeking the objective of price stability but simultaneously minimizing the potential adverse effects on output. To this end, the key ingredient is to continue along the path of strengthening central banks' reputation and credibility. ${ }^{28}$ The more solid is central banks' reputation and credibility, the lower are real interest rates required to maintain simultaneously price stability and a stable path of output growth. Achieving this goal depends on the combination of policy and institutional factors.

Implementing a more efficient monetary policy hinges not only on central banks' ability to conduct monetary policy, but also on making central banks' policy more transparent and predictable. ${ }^{29}$ In this connection, while central banks in the region, especially IT central banks, have already enhanced accountability and transparency standards following their institutional reform, there is still room for improvement. Based on the international standards for measuring the transparency of monetary policy, Latin America ranks behind Europe,

${ }^{28}$ The difference between these two policy features is subtle and difficult to separate. One form of separating these two concepts is to associate reputation with the stock of monetary policy successes - the accumulated past achievements in terms of inflation-and to link credibility with the public's assessment of current monetary policy (Siklos, 2002).

${ }^{29}$ The link between more transparency and less inflation has not received much attention in the literature, but it is subject of increasing interest by academics and practitioners. Chortareas and others (2002) provide empirical support in industrial countries. 
Asia, and Middle East and Central Asia in terms of its transparency of monetary policy. ${ }^{30}$ As illustrated in Figure 4, the percentage of criteria of the code of transparency of monetary policy that are "fully observed" or "broadly observed" is 76 percent in Latin America against more than 90 percent, both in Asia and Europe, and 80 percent in Middle East and Central Asia. $^{31}$

Figure 4. Transparency of Monetary Policy

(Latin America versus other regions)

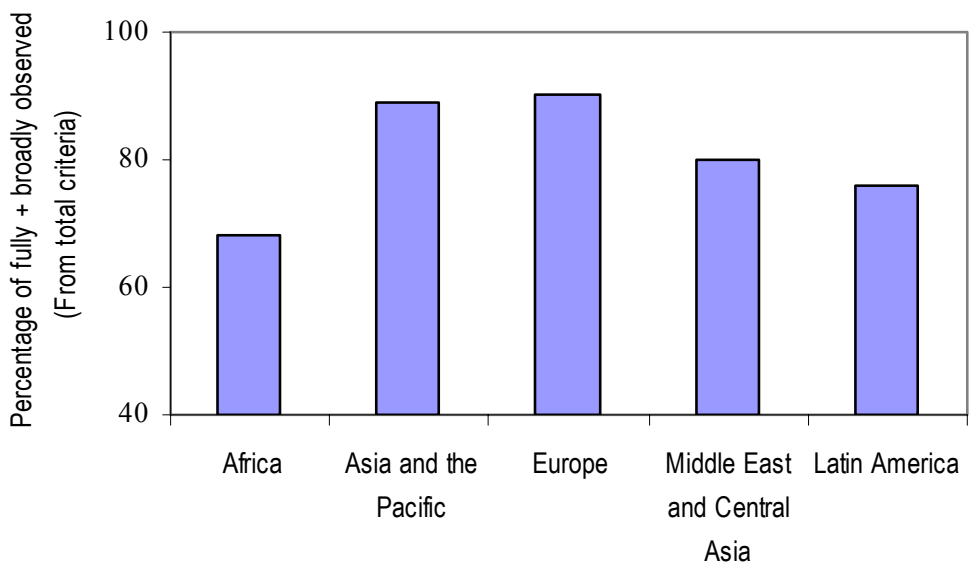

Source: Standards and Codes Gateway (Monetary and Financial Systems Department, IMF).

In addition to what central banks can do to fulfill their mandate of arresting inflation, their autonomy should receive the support of governments and societies. At present, the record of instability of central bank governors in their posts raise concerns about whether central banks are autonomous in practice. Using the turnover rate of central bank governors as a proxy for effective central bank independence, ${ }^{32}$ we found that the average rate in Latin America is

${ }^{30}$ See the IMF's Transparency Code for Good Practices in Monetary and Financial Policies: Declaration of Principles (1999). The assessment of transparency practices is conducted on a qualitative basis using five categories: observed, broadly observed, partially observed, nonobserved, and not applicable.

${ }^{31}$ The sample in Latin America includes most countries except for some key players like Argentina, Uruguay, and Venezuela.

${ }^{32}$ A similar indicator has been used previously in the literature (see Cukierman, 1992 and more recently, De Haan and Kooi, 2000), although it has also been criticized under the argument that it may also imply a lack of political autonomy, as docile central bank governors will have better chances of remaining in their posts. 
approximately $0.4 .^{33}$ Thus, in average, a central bank governor remains in office for about two and a half years. This period, however, is clearly less than the term of appointment of central bank governors in the region - typically between four and six years. In addition, it is well below the effective term of central bank governors in industrial countries. ${ }^{34}$ By country, Bolivia, Colombia, and Mexico seem to have the most stable central bank authorities, whereas Brazil and Ecuador feature the least stable (Figure 5). ${ }^{35}$ The high rate of turnover of central bank governors in a number of Latin American countries suggests that monetary authorities remain vulnerable to political pressures and to periods of political instability.

Figure 5. Turnover Rate of Central Bank Governors

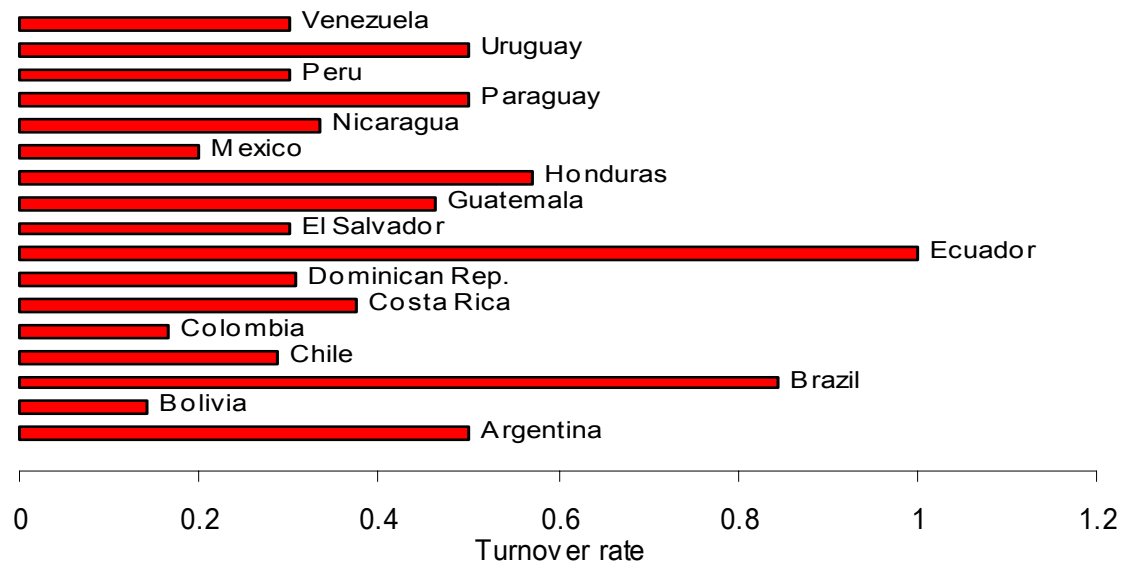

\footnotetext{
${ }^{33}$ The turnover rate of central bank governors was obtained by dividing the number of central bank governors by the number of years following the enactment of the new law that instituted central banks' autonomy in each country - until 2003. Thus, the lower is this rate, the more stable have been central banks authorities, and presumably, more independent they have been from a political perspective.
}

${ }^{34}$ For the sake of comparison, the Chairman of the Board of Governors of the U.S. Federal Reserve remains in post since 1987, whereas in the Bank of Canada and the Bank of England the latest governors remained in their posts during the whole term to which they were appointed-7 and 10 years, respectively.

${ }^{35}$ For Ecuador, the rate corresponds to the period 1992-1999 and for El Salvador 1991-2000, when the central bank reform was adopted and before dollarization was formally instituted in each country. For Brazil, the Dominican Republic, and Guatemala, the whole period 19902003 was applied. 


\section{B. Restore Confidence in Domestic Currencies}

A second key challenge facing most central banks in Latin America is to restore markets' confidence in the national currencies. This is in general a legacy of periods of high inflation experienced by a number of countries in the region. The central banks affected by this problem can be divided into two groups: (i) those that decided to sacrifice their monetary "independence" by tying their currency, to one degree or another, to the U.S. dollar in order to reduce inflation; and (ii) those which have not yet recovered their monetary independence following past episodes of high inflation and/or financial instability. ${ }^{36}$

\section{The case of countries that have tied their currency to the U.S. dollar}

This first group consists primarily of some countries in Central America. As small and very open economies with close ties to the United States, these countries increasingly adopted the U.S. dollar as a means of payment; meanwhile, given that exchange rate fluctuations exert a significant influence on price formation in the economy, central banks decided to use the exchange rate as a nominal anchor to guide inflation expectations. In this environment, dollarization of liabilities became increasingly high, to the point where real depreciations could inflict a marked negative impact on the financial obligations of individuals, companies, and the government. This potential damaging effect led central banks to the so-called "fear of floating" the exchange rate. ${ }^{37}$ In any case, prudent fiscal policies in most countries and capital inflows from abroad favored the sustainability of exchange rate pegs.

Without question, the use of an exchange rate anchor has helped to bring down inflation. But it is also true that this policy regime also bears costs and vulnerabilities. The main drawback is the lack of a rapid and low-cost exit strategy from the exchange rate peg, which is critical in light of recurrent real and financial shocks that hit most countries in the region. In addition, the use of an exchange rate peg precluded central banks from conducting monetary policy, and hence developing the skills necessary to formulate and manage monetary policy and building institutional credibility was relegated to a secondary place. This turned into a costly shortcoming when the countries were forced to exit the peg, for example in the midst of a financial crisis.

Looking ahead, the central banks of this group of countries need to assess whether it is wise to continue with the current monetary regime or to shift to an alternative scheme. This means weighing the benefits of keeping the exchange rate anchor-once inflation has been brought down to single-digit levels but still without lowering it to the international inflation levelagainst the potential costs embedded in such a regime. If the decision is to stay with the peg,

\footnotetext{
${ }^{36}$ There are also countries such as Chile, Colombia, and Mexico that have achieved a position of monetary independence.

${ }^{37}$ See Calvo and Reinhart (2002).
} 
the central banks will need to maintain a higher level of international reserves than would be necessary under a flexible regime, to assure the markets that the exchange rate will be held stable, even in the face of exogenous and policy-induced shocks. In addition, although fiscal discipline and the soundness of the financial system are necessary conditions for the proper functioning of any monetary regime, they are especially important under fixed or quasi-fixed exchange rate regimes because of the devastating macroeconomic consequences of a disorderly exit from the peg stemming from loose fiscal and financial polices. This is the lesson of several recent episodes, in which exchange rate anchors were abandoned in the midst of fiscal and/or financial crises exerting very high macroeconomic costs (Argentina, Brazil, Ecuador, and Mexico are valid cases in point).

Should the decision be to migrate to a flexible exchange rate regime, the transition should be gradual. This strategy will give the central banks time to learn how to conduct monetary policy and improve their understanding of monetary policy transmission. Simultaneously, the central banks would have to invest in building reputation and gaining credibility, based on their ability to meet monetary targets and reduce inflation, an objective that can only be achieved over time.

Under a flexible exchange regime, a relevant question is whether central banks should pursue a monetary targeting strategy or if they should adopt an IT regime. This query relates to the debate about whether IT regimes demand pre-requirements for its implementation. There is no consensus on this issue. Some consider that certain prerequisites are desirable but not essential, since the adoption of an IT regime brings about an endogenous learning process over time (see Truman, 2003, for example). Our view is that, before announcing a commitment to an IT scheme, central banks must put in place some fundamental conditions to assure the proper functioning of the new regime and minimize the risk of initial failures, which may undermine the success of the IT regime. The following four conditions should be included at the very least: (i) having an appropriate legal framework which identifies price stability as central bank's primary objective, empowers the central bank with political and operational independence to achieve such objective, and establishes rigorous accountability and transparency mechanisms; (ii) eliminating for practical purposes any other primary goal, whether explicit or implicit, and especially any goals involving the exchange rate; (iii) eliminating fiscal dominance, if it exists; and (iv) strengthening the financial system. ${ }^{38}$ On the other hand, having in place basic institutional capacities may also be crucial to run a policy regime that relies on more sophisticated expertise. In addition, countries featuring low developed financial markets and a stable money demand, may find more effective and easier to handle a monetary targeting regime.

If countries irreversibly abandon their currency, thereby giving up their right to make monetary policy, the question is whether there is any reason for the existence of a central

\footnotetext{
${ }^{38}$ Carare et al. (2002) contains a detailed discussion of the initial conditions that need to be established in order to support an IT regime.
} 
bank. So far, none of the recently dollarized economies in Latin America-Ecuador and El Salvador - has tackled this question formally, and so their central banks continue to exist, performing tasks of secondary importance vis à vis central bank's basic functions of issuing money and conducting monetary policy. ${ }^{39}$ Operating these institutions, however, bears costs that society has to pay. An alternative to maintaining the costly status quo or to closing down central banks would be to give them the fundamental responsibility of financial supervision, by taking over or merging them with the public institutions in charge of these duties - and perhaps having them continue performing other secondary functions as they do now.

\section{The case of countries that have a legacy of past periods of inflation}

A number of central banks in the region succeeded in reducing inflation but failed to restore full confidence in the domestic currencies. Although inflation has been significantly reduced, and in some countries brought down to the world level, the years of macroeconomic instability are still alive in the market participants' mind. As a result, certain distortions endure, particularly a high level of financial dollarization and the so-called "peso problem."

Financial dollarization in Latin America is very high, reaching in some cases about 90 percent like in Bolivia and Uruguay. After several years - and even decades - of high inflation in a number of countries in the region, markets have not recover confidence in the domestic currency, in particular in terms of its role as a store of value. As a result, financial dollarization rocketed during the 1990s despite the decline in inflation (Figure 6). While financial dollarization entails some benefits, it also brings about costs and distortions. ${ }^{40}$ In terms of monetary policy, as money base in domestic currency shrinks, central banks have only a small room for maneuver. Moreover, in light of high liability dollarization, central banks feel "fear of floating" and are compelled to maintain sizeable volumes of international reserves as a buffer to tackle potential speculative attacks and banking crises featuring large deposit withdrawals. As a result, a vicious circle is set in motion since the lack of exchange rate flexibility leads market participants to take further foreign currency risks; these enhances dollarization and strengthens central banks' "fear of a floating," thereby reinforcing exchange rate inflexibility.

\footnotetext{
${ }^{39}$ In those countries central banks perform the role of fiscal agency, regulate and coordinate the payment system, invest international reserves, carry out macroeconomic studies, and recover portfolio assets which were pledged as collateral in exchange for the loans granted during previous episodes of banking crises

${ }^{40}$ An assessment of the risks and benefits of financial dollarization is out of the scope of this document. This analysis is conducted in De Nicolo, Honohan, and Ize (2005).
} 
Figure 6. Financial Dollarization and Inflation in Selected Latin American Countries
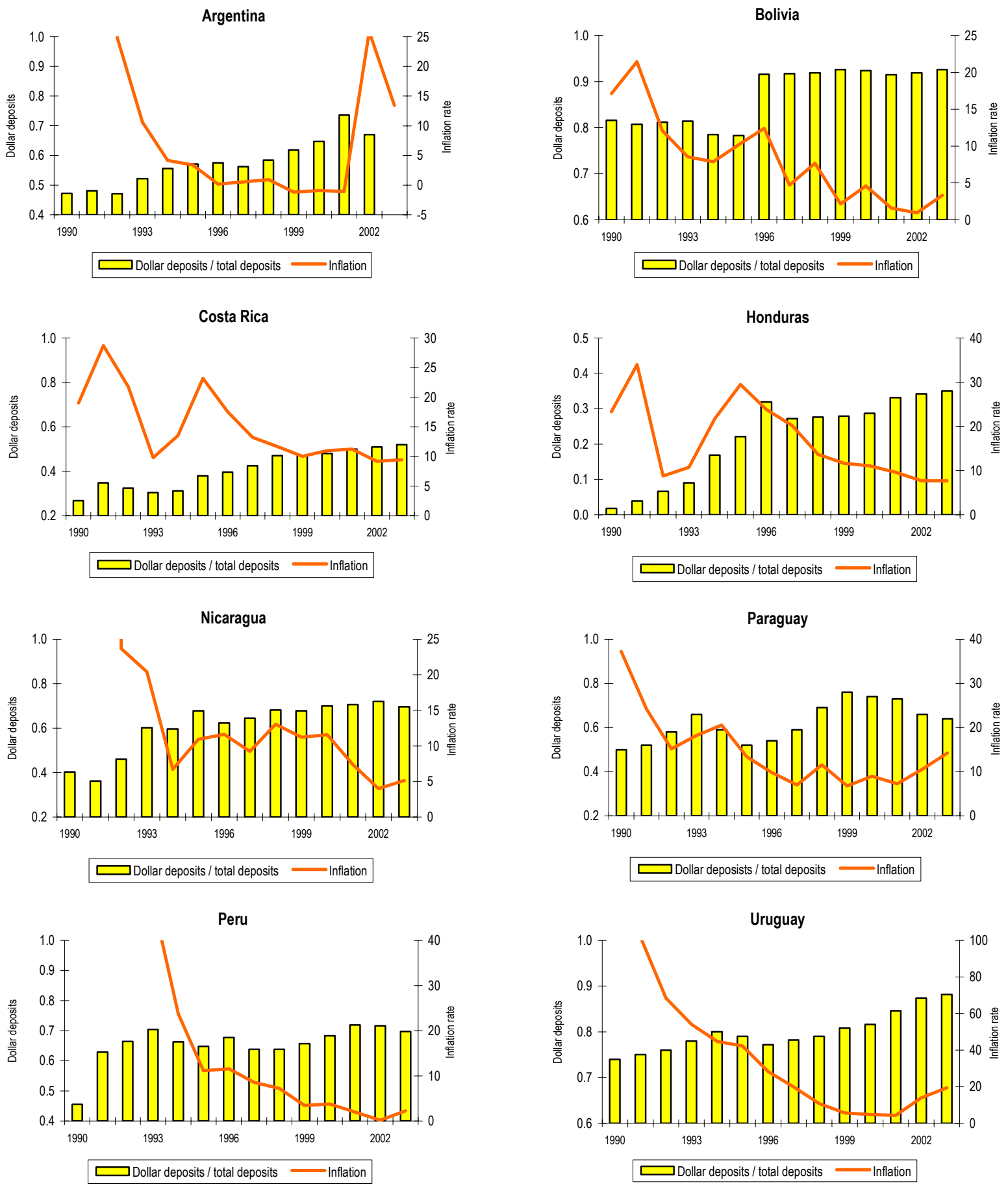

Source: International Financial Statistics, IMF. 
The "peso problem" is typically manifested by high real interest rates in domestic currency. It represents the markets' perception of a potential risk, albeit minimum, of a sudden depreciation of the domestic currency. Strictly speaking, high real interest rates also capture "country risk" and "banking crises risk," and hence, they emerge in light of periods of fiscal fragility and/or financial instability. High real interest rates are observed in a number of countries in the region, as observed in Figure 7, but are a particularly distorting feature in Brazil.

Figure 7. Real Interest Rates in Selected Latin American Countries (Spread on U.S. real interest rate)
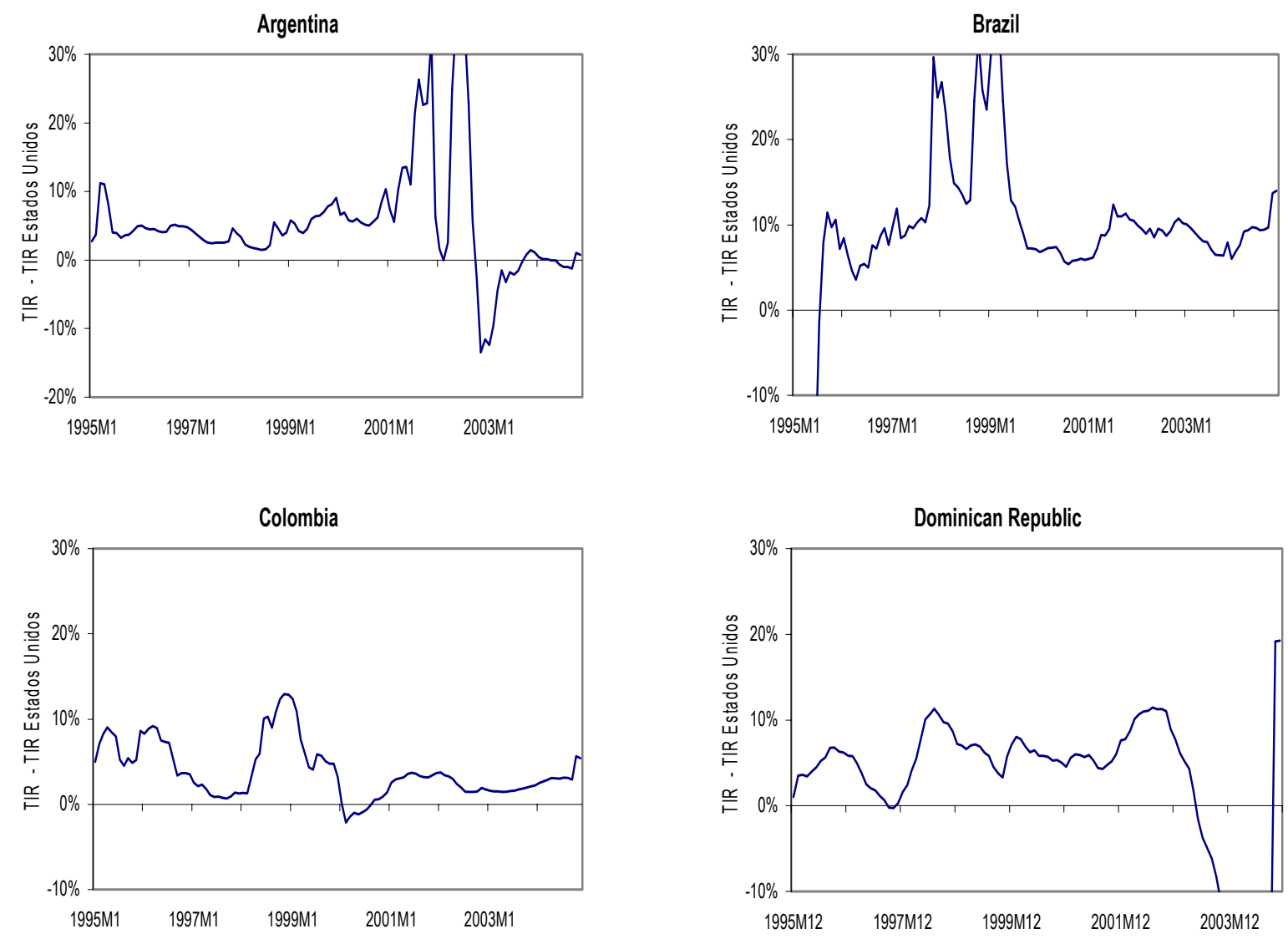

Source: International Financial Statistics, IMF.

Correcting these distortions - high financial dollarization and the "peso problem"-will take a considerable length of time and will require the support of certain government policies. The institutional strengthening envisaged in the legal reform of central banks has been a major step in the right direction, complemented with the modernization of the design and execution of monetary policy and the implementation of policies aimed at building institutional capacity. However, central banks need to persevere in consolidating their reputation by 
systematically meeting their inflation targets, on the basis of maintaining operational independence within long-term decision-making horizons, and enhancing accountability and transparency.

In terms of government policies, strengthening prudential regulations applicable to foreign exchange transactions is crucial to reestablish an independent monetary policy. While a set of good practices is still nonexistent, a number of measures may be adopted with the aim of encouraging the use of local currency vis à vis the U.S. dollar or other foreign currency. For instance, rising capital requirements in light of increases in foreign currency loans will take its toll on bank shareholders and will discourage borrowing in foreign currency. Establishing differentiated insurance premiums - within deposit insurance systems - to penalize foreign currency deposits will also act as an incentive for de-dollarizing financial systems. Nevertheless, these measures could work provided they are adopted in an environment of macroeconomic stability. Other than these, de-dollarization efforts should be part of a broad strategy based on national consensus about economic, political, and social foundations for long-term stability and economic growth, which also seems to be necessary to restore confidence in domestic currencies.

\section{How to Cope with Capital Inflows While Maintaining Policy Consistency}

Monetary policy consistency is instrumental to underpin credibility, a key pre-requisite to achieve long-run price stability. If markets are unable to anticipate and understand the decisions of central banks, and if central banks lack a consistent policy reaction function, monetary policy will be less effective in reducing inflation and the existence of an inflation bias will perpetuate. In this environment, monetary policy efforts directed to reduce inflation will demand higher interest rates than otherwise, which will imply a higher "sacrifice ratio."

Following the institutional reform of central banks, policy inconsistency decreased significantly in Latin America as political influence on central bank decisions was mostly eradicated. Nonetheless, while policy surprises associated to sudden monetary expansion became less important, inconsistencies remained in a few central banks, this time as a result of using the exchange rate as nominal anchor to reduce inflation. Central banks targeting the exchange rate tend to devote their energies to defend the exchange rate peg, which at times were in conflict with policies aimed at achieving price stability.

The recent surge of capital inflows has put additional pressure on the consistency of monetary policy in the Latin American economies. As capital inflows soared, domestic currencies tend to appreciate, leading central banks to the dilemma of whether or not to intervene in the exchange rate market to avoid a real appreciation. The 2004-2005 oil supply shock has further complicated central banks' policy response to capital inflows as it triggered a slight rebound in inflation in many countries. To keep inflation pressures-even if they are only moderate - from contaminating wage negotiations and other contracts, in many cases central banks have increased interest rates. However, higher interest rates have attracted additional capital inflows, thereby exacerbating appreciation pressures on the domestic 
currencies. Similar issues have arisen in oil exporting countries in the region, given the significant increase in oil revenues as a result of the spike in crude prices.

As oppose to the recent past, today the real appreciation of domestic currencies is not welcome any more. In 2004, most central banks in the region, including some of them working in an IT framework, have been intervening in the exchange market to mitigate real appreciation pressures. ${ }^{41}$ At least two factors help to explain the opposition to accept today's appreciation trend. The first is that inflation in the region is not perceived any more as a problem, and hence, the appreciation of the domestic currencies appears generating only costs but no benefits. The second factor is the loss of competitiveness of exports as today they face a fierce foreign competition, especially from Asia, which puts at risk investment and employment.

As illustrated in Figure 8, a number of central banks - Colombia, Guatemala, and Peru are some examples in the region-have followed the course of exchange market intervention. As a result, international reserves held by the central bank, as well as the stock of central bank/government bonds have increased, leading to a negative impact on central banks' income statements. In turn, a few central banks in the region decided not to intervene in 2004, or they did it on limited amounts, like Brazil, Chile, and Mexico. ${ }^{42}$

None of these two policy alternatives is cost free, but probably central banks' intervention is more costly in a long-term perspective. While foreign exchange interventions are not abnormal, even in IT emerging markets, the problem is really the reason behind such intervention. A frequent and/or abundant intervention may signal the purpose of preserving external competitiveness, and not simply, for instance, the desire of mitigating short-term episodes of exchange rate volatility. The nature of this intervention raises concerns about central banks caring about the competitiveness of exports - an objective not envisaged in central banks' charter - which at times may be in contradiction with the objective of price stability. Moreover, one can question the de facto independence of monetary policy because central banks intervention may well respond to external pressures indirectly exertedthrough the government-by market participants, which lose with the appreciation of the domestic currency.

\footnotetext{
${ }^{41}$ Intervention has taken place not only by outright sales of international reserves, but also using financial instruments such as options and swaps.

${ }^{42}$ In 2005, however, Brazil has stepped up foreign exchange intervention to moderate exchange rate appreciation and strengthen its international reserves.
} 
Figure 8. Response to Capital Inflows in Selected Latin American Countries
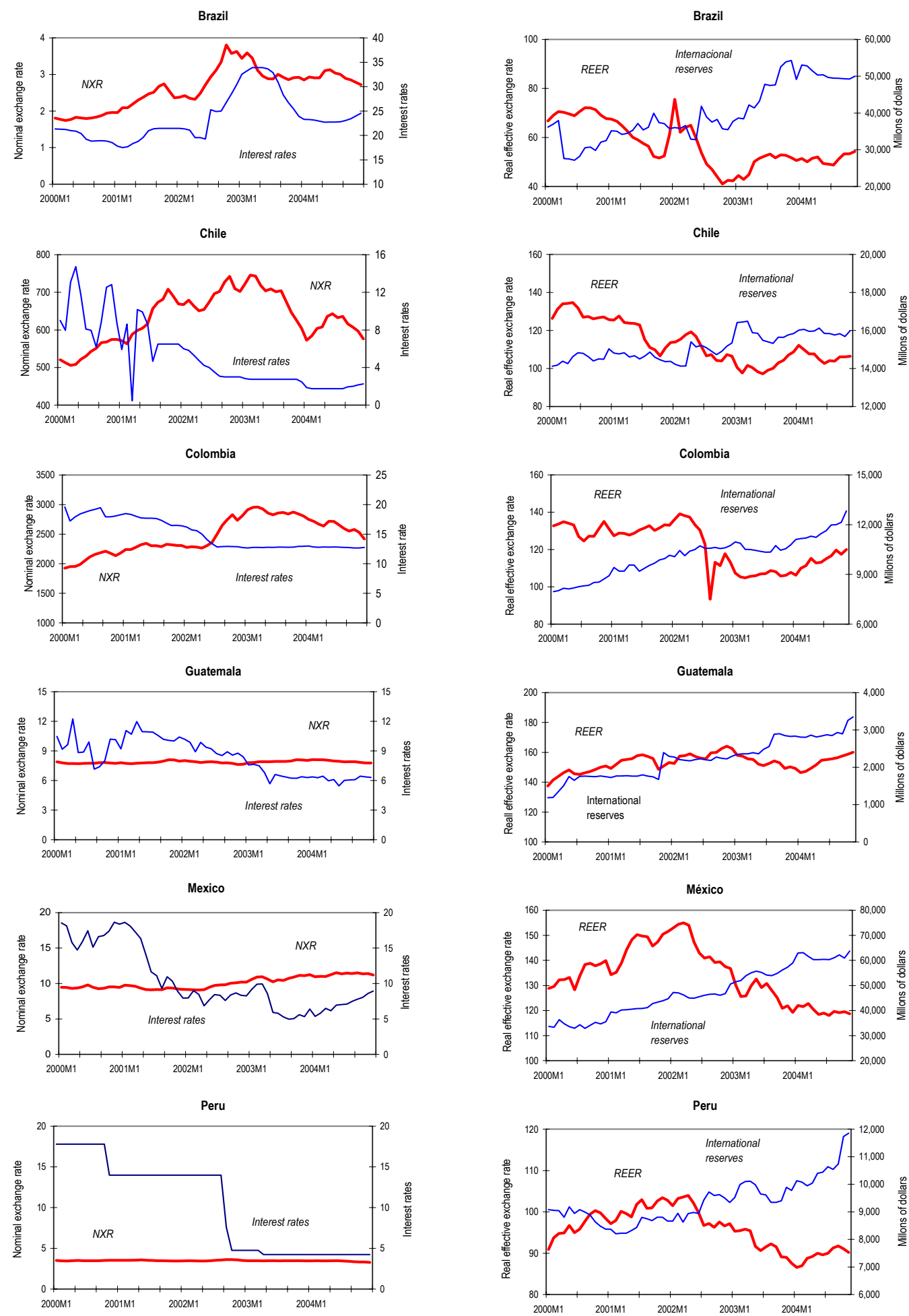

Source: International Financial Statistics, IMF. 
Furthermore, central banks' intervention may be damaging from an institutional standpoint, in particular for IT central banks. Given that IT central banks in the region have publicly committed with price stability as their fundamental objective, switching to a policy of avoiding exchange rate appreciation may revive concerns about policy conflicts, as the appreciation would help to curb inflation pressures. Furthermore, switching short-term policy emphasis to focus on exchange rate stability will damage central banks' predictability, a key feature in which central banks have made a valuable and sustained investment.

On the other hand, when central banks do not intervene in the foreign currency market, the appreciation trend will eventually disappear, provided domestic interest rates adjust downward to eliminate differentials vis-à-vis the world interest rate. In the event that a real appreciation materializes, this may help to moderate inflation pressures stemming from the oil shock. On the other hand, to cope with the cost on tradable activities, domestic producers may have to absorb the losses. In the long-run, central banks may not be very effective in containing the real appreciation because the real exchange rate is an endogenous variable. Thus, the appropriate way to mitigate the effects of the real appreciation is that tradable activities increase productivity.

Current exogenous shocks stress the need of additional structural changes in Latin America, in particular in the labor market. Making the economies more flexible will allow them to better adjust to moderate the adverse effects of exogenous shocks. It may also allow to soften the cyclical pattern of the real exchange rate, which tend to evolve in the long-run through an equilibrium path (Figure 9).

\section{The Perils of Financial System Weaknesses and the Lack of Fiscal Discipline}

While the objective of price stability is clearly a central bank responsibility, it may not be attainable and, in particular, may not be sustainable in the long-run, without the support of other conditions that are out of the scope of central banks. Two key threatens to the objective of price stability are potential financial system weaknesses and the persistent lack of fiscal discipline. ${ }^{43}$ These two distortions can place an upward pressure to interest rates and eventually may trigger a rebound in inflation.

\section{The need to preserve sound financial systems}

Banking crises have been a common and recurrent event in Latin America with disastrous macroeconomic and social effects (Carstens et al., 2004). In particular, since 1990, banking crises have been the main cause of inflation reversals and economic contraction in a number of countries (see Figure 10). From a microeconomic perspective, in a number of episodes the management of systemic crises left a legacy of market discipline relaxation as a result of the

${ }^{43}$ In this paper we are assuming that financial systems' surveillance is not a central bank responsibility, like in the majority of countries in Latin America. 
Figure 9. Real Exchange Rate in Latin America and Subregions
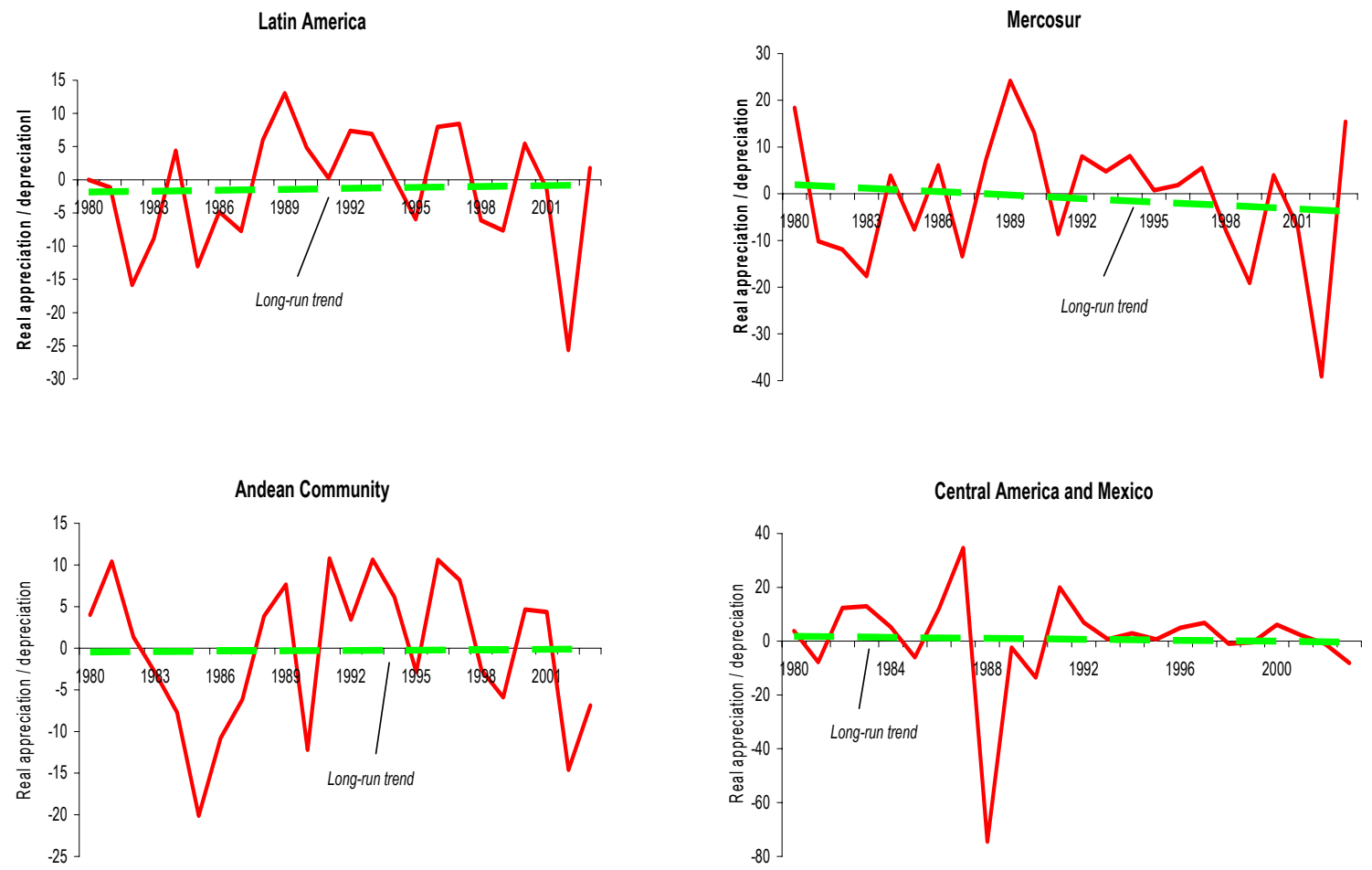

Source: Western Hemisphere Department, IMF.

provision of blanket guarantees and widespread debt restructuring, while depositors' confidence suffered a long-term damage because of breaches of contracts such as freezing and reprogramming of deposits.

Central banks in Latin America have been intensively involved in the management of banking crises and resolution, whether or not the crisis posed a systemic threat. The resulting monetization was not free of costs. On the contrary, it exacerbated macroeconomic instability, including in a number of cases a simultaneous banking and currency crisis. Central banks' participation in bank resolution also damaged their financial position as a result of the purchase of assets - received in exchange for liquidity and solvency loans provided in the midst of the crises - which were very difficult to recover overtime. 
Figure 10. Effects of Banking Crises on Growth and Inflation in Latin America
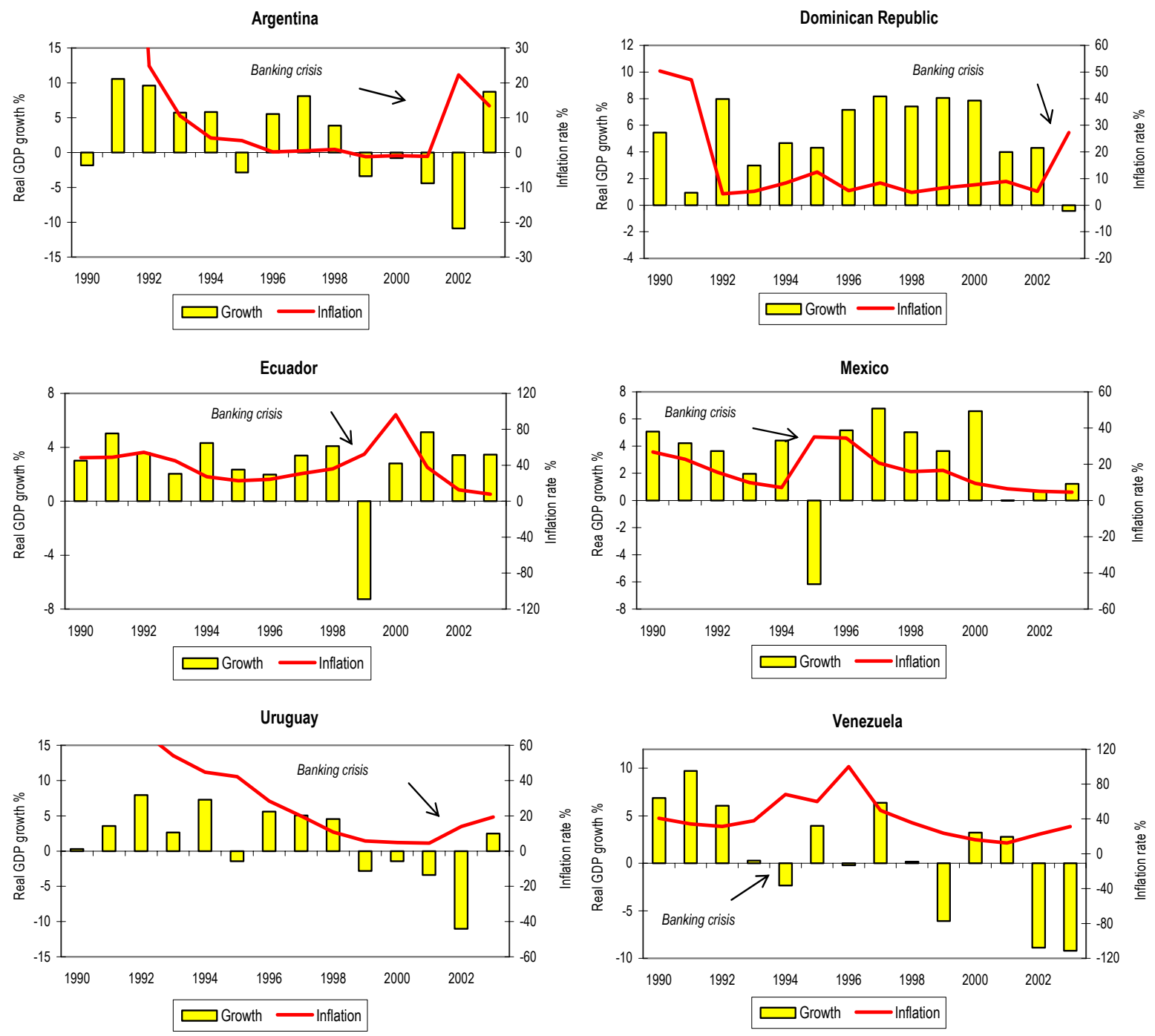

Source: International Financial Statistics, IMF.

Most countries in the region have made progress in establishing an appropriate framework for preventing and managing banking crises, but more needs to be done. The new reforms must emphasize precautionary regulations because the experience shows that once a crisis erupts the costs are inexorably high. Thus, countries should focus on improving early warning mechanisms and, more important, on empowering bank regulators to act effectively at an early stage to deal with incipient banks liquidity and solvency problems. ${ }^{44}$ In addition,

${ }^{44}$ The experience of recent banking crises in Latin America shows that bank regulators tend to act when liquidity and solvency problems were already irreversible. 
the legal framework for bank restructuring and resolution must be improved to allow countries to manage and resolve banking crises in an effective way. Major reforms and new procedures should facilitate and make more effective the conduct of "purchase and assumption" operations as the main instrument of bank resolution. The costs of the crisis should be absorbed by financial institutions' shareholders and by large depositors, whereas any residual cost should be borne by the government and not by the central bank.

As part of this reform, the role of central banks in the prevention and management of banking crises should be clearly established in law. Leaving open the door for the monetization of banking crises may threaten central banks' objective of price stability and may pose moral hazard risks. Central banks may be under pressure to provide easy money to finance banking crises, in particular in countries that feature weak institutions, thereby amplifying macroeconomic instability. Having generous access to central bank resources is equivalent to providing leeway to bankers and depositors to take excessive risks. In turn, governments may feel encouraged to postpone banking resolution decisions as they count at any time on low cost funds from the central bank, without measuring properly the potential costs of delaying decisions aimed at adopting lasting bank resolution decisions.

Regulations to restrict central banks' involvement in banking crises must be integral part of the legal reform aimed at preventing and managing banking crises. Furthermore, once the regulations to manage banking crises and resolution are in place-based on the use of private sector and fiscal resources - legal provisions should be in effect to limit monetization of banking crises. Regarding lender-of-last-resort assistance, it should be bounded to short-term loans directed to illiquid but solvent banks. Restricting central banks' participation in banking crises resolution and restructuring will limit macroeconomic instability. ${ }^{45}$

\section{The importance of having strong public finances}

A second key potential source of vulnerability to price stability in Latin America is the reemergence of fiscal deficits. After an initial period of fiscal consolidation during the early 1990s in most countries in the region, fiscal deficits - measured in terms of the ratio of the non-financial pubic sector deficit to GDP-have soared again in a number of countries (see Figure 11). While public expenditure financing from central banks is already restricted following the institutional reform of central banks, increasing fiscal deficits are conducive to a pick up in public debt as the only remaining source of government financing.

\footnotetext{
${ }^{45}$ Jácome (2005) analyzes 20 episodes of banking crises in Latin America during the 1990s and 2000s and claims that when central banks monetized the crises macroeconomic instability was larger, and vice versa.
} 
Figure 11. Fiscal Deficit in Selected Latin American Countries (moving average $t=3$ )
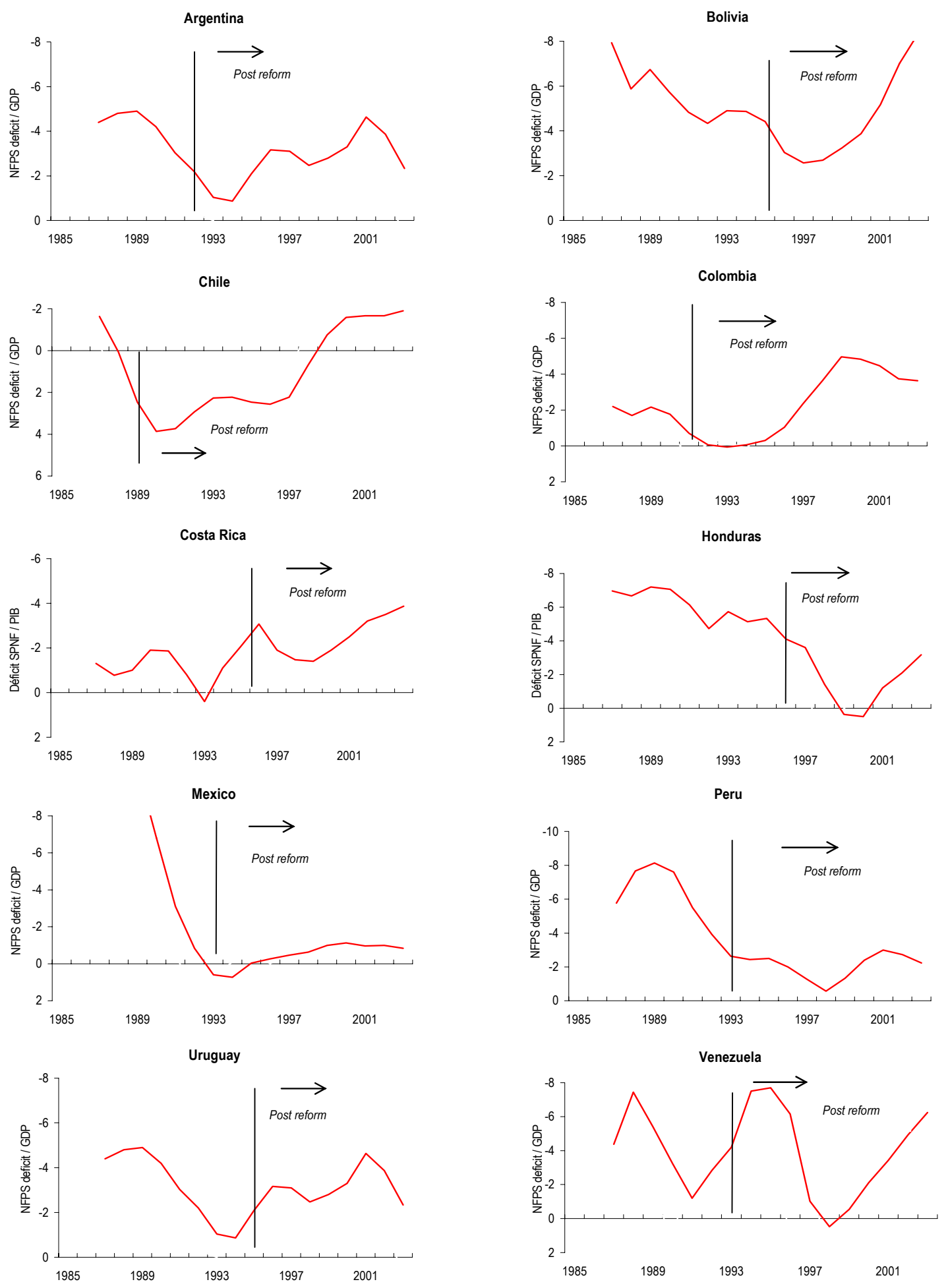

Source: International Financial Statistics, IMF. 
The effect of a lack of fiscal discipline and an increasing debt burden is that countries may feature high real interest rates and a surge in "country risk" indicators. A tight monetary policy combined with a loose fiscal stance produces an inconsistent policy mix, which leads to an upward trend in interest rates as central banks multiply efforts to preserve markets' confidence on inflation targets. In an environment of high interest rates, the room of maneuver of monetary policy is limited and conducive to an enhanced "sacrifice ratio." In the limit, the deteriorating fiscal stance may turn unsustainable, thereby leading to a currency crisis, like in Brazil in 1999, or to a banking-currency-sovereign debt crisis, like in Argentina en 2002 .

In light of a potential additional deterioration of public finances, a number of Latin American governments have the responsibility of reestablishing fiscal discipline to underpin central bank efforts to abate inflation. Central banks can do little to curb inflation expectations associated to large fiscal deficits and an unsustainable public debt, except rising interest rates - which may not be sustainable in the current juncture - as a way of alerting the markets about the perils of lax fiscal policies in relation to their medium and long-run objective of achieving price stability. An alternative course of action could be that governments approve "fiscal responsibility laws," like those already enacted in countries like Brazil and Ecuador, which seems to be providing encouraging results.

\section{CONCluding Remarks}

Recent major developments in monetary policy in Latin America are of an institutional nature. A major central bank reform was adopted in almost all countries in the region, which focused their mandate on seeking and preserving price stability, enhanced central banks' autonomy, in particular, in the use of monetary instruments, and held them accountable with respect to the actions adopted to attain their policy mandate. Under this new institutional framework, monetary policy has modernized and inflation has dropped to single-digit rates in a majority of countries of the region. Empirical evidence indicates that the legal independence of central banks, in conjunction with other macroeconomic policies, has contributed to this result.

Today, central banks need to address three important challenges. First, to drive inflation to international levels, as a measure of price stability, minimizing at the same time the "sacrifice rate" associated with the disinflation process. Second, to foster confidence in the domestic currencies, not only as a means of payment, but also as a store of value, to reduce the vulnerabilities stemming from dollarization and to enhance monetary policy's room of maneuver. And third, to maintain the consistency of monetary policy in the wake of the new wave of capital inflows, which is fueled by a propitious international environment and attracted by improved stability conditions and favorable regional prospects.

While an enhanced reputation and credibility will be key to successfully overcoming the first challenge - at least from the part of central banks - this may not be sufficient to restore confidence in the domestic currencies in a number of countries in the region. De-dollarization is expected to take place gradually as a result of maintaining solid macroeconomic 
fundamentals and the adoption of microeconomic regulations aimed at discouraging transactions in foreign currency. Likewise, measures to weather distortions created by capital inflows also require a strategy that exceeds central bank responsibilities, given the political economy implications of the resulting appreciation trend of domestic currencies. Despite the short-term toll that a market solution may take on the competitiveness of tradables, it might be less costly in the long-run than the alternative of intervening in the foreign exchange market. The intervention strategy may damage the credibility of central banks, thereby potentially impairing further efforts to abate inflation. In addition, the sterilization of exchange rate interventions will imply an indirect subsidy to tradable activities resulting from the negative impact on central banks' income statements, which could turn into a quasi-fiscal deficit. Alternatively, the short-term loss of competitiveness should be absorbed by producers, whereas governments should compensate the long-run loss of competitiveness via structural reforms to make the economies more flexible to cope with adverse shocks.

In general, central banks will not succeed in their endeavors unless governments ensure global macroeconomic stability and the viability of countries. In particular, central banks success also hinges on governments' abilities to preserve the soundness and stability of the financial systems and to keep fiscal deficits in check. Finally, governments should make sure that actions speak louder than words in supporting the autonomy of central banks, demanding in exchange rigorous accountability and transparency procedures from monetary policy. 


\section{REFERENCES}

Andersen, P., and W. Wascher, 1999, "Sacrifice Ratios and the Conduct of Monetary Policy in Conditions of Low Inflation,” BIS Working Papers, No. 82 (Basel: Bank for Internaitonal Settlements).

Barro, R., and D. Gordon, 1983, "A Positive Theory of Monetary Policy in a Natural Rate Model," Journal of Political Economy, Vol. 91, pp. 589-610.

Brumm, H., 2000, "Inflation and Central Bank Independence: Conventional Wisdom Redux," Journal of Money, Credit, and Banking, Vol. 32, pp. 807-19 (November).

Bubula, A., and I. Ötker-Robe, 2002, "The Evolution of Exchange Rate Regimes since 1990: Evidence from De Facto Policies," IMF Working Paper 02/155 (Washington: International Monetary Fund).

Carare, A., A. Schaechter, M. Stone, and M. Zelmer, 2002, "Establishing Initial Conditions in Support of Inflation Targeting," IMF Working Paper 02/102 (Washington: International Monetary Fund).

Carstens, A., D. Hardy, and C. Pazarbaşioğlu, 2004, "Banking Crises in Latin America and the Political Economy of Financial Sector Policy." Document presented at the seminar Gobiernos y Bancos: Responsabilidades y Limites. Inter-American Development Bank, Annual Meetings, Lima, Peru (March).

Chortareas, G., D. Stasavage, and G. Sterne, 2002, "Monetary Policy Transparency, Inflation, and the Sacrifice Ratio," International Journal of Finance and Economics, Vol. 7, pp. 141-155.

Cukierman, A., 1992, Central Bank Strategy, Credibility, and Independence: Theory and Evidence (Cambridge, Massachussetts: The MIT Press).

— , P. Miller, and B. Neyapti, 2002, "Central Bank Reform, Liberalization, and Inflation in Transition Economies - An International Perspective," Journal of Monetary Economics, Vol. 49, pp. 237-64.

De Haan, J., and W. Kooi, 2000, "Does Central Bank Independence Really Matter? New Evidence for Developing Countries Using a New Indicator," Journal of Banking and Finance, Vol. 24, pp. 643-64.

De Nicoló. G., P. Honohan and A. Ize, 2005, "Dollarization of Bank Deposits: Causes and Consequences," Journal of Banking and Finance, Vol. 29, pp. 1697-1727. 
Edwards, S., 1995, Crisis and Reform in Latin America: From Despair to Hope (Oxford and New York: Oxford University Press).

Eijffinger, S., and E. Schaling, 1993, “Central Bank Independence in Twelve Industrial Countries," Banca Nazionale de Lavoro Quarterly Review, No. 184 (March), pp. $49-89$.

_, E. Schaling, and M. Hoeberichts, 1998, "Central Bank Independence: A Sensitivity Analysis," European Journal of Political Economy, Vol. 14, pp. 73-88.

Fischer, S., 2001, “Exchange Rate Regimes: Is the Bipolar View Correct?” Journal of Economic Perspectives, Vol. 15, No. 2 (Spring). , 1995, Modern Central Banking. En Capie, F., et.al. Eds. The Future of Central Banking (Cambridge: Cambridge University Press).

Fischer, A.M., 1996, "Central Bank Independence and Sacrifice Ratios," Open Economies Review, Vol. 7, pp. 5-18.

Fuhrer, J., 1997, “Central Bank Independence and Inflation Targeting: Monetary Policy Paradigms for the Next Millennium?" New England Economic Review, pp. 19-36 (January/February).

Grilli, V., D. Masciandaro, and G. Tabellini, 1991, "Political and Monetary Institutions and Public Financial Policies in the Industrial Countries," Economic Policy: A European Forum, Vol. 6, pp. 342-91 (October).

Gartner, M., 1997, "Central Bank Independence and the Sacrifice Ratio: The Dark Side of the Force," Schweizerische Zeitschrift fur Wolkswirtschaft und Statistik, No. 133, pp. 513-38 (September).

Jácome, L., 2005, “Central Banks Involvement in Banking Crises and Resolution in Latin America: Not a Free Lunch," forthcoming IMF Working Paper, (Washington: International Monetary Fund).

2003, "Independencia Legal de la Banca Central en la América Latina e Inflación," El Trimestre Económico, Vol. LXX(4), pp. 673-719, Mexico, D.F (OctoberDecember).

— , and F. Vázquez, 2005, “Any Link Between Legal Central Bank Independence and Inflation? Evidence from Latin America and the Caribbean” IMF Working Paper 05/75, (Washington: International Monetary Fund).

Kydland, F., and E. Prescott, 1977, "Rules Rather than Discretion: The Inconsistency of the Optimal Plans," Journal of Political Economy, 85, pp. 473-491. 
Lora, E., 2001, "Structural Reforms in Latin America: What Has Been Reformed and How to Measure It," Research Department Working Paper No. 466, (Washington: Inter-American Development Bank).

Loungani, P., and N. Sheets, 1997, "Central Bank Independence, Inflation, and Growth in Transition Economies," Journal of Money, Credit, and Banking, Vol. 29, No. 3, pp. 381-99 (August).

Rogoff, K., 1985, “The Optimal Degree of Commitment to an Intermediate Monetary Target," Quarterly Journal of Economics, pp. 1169-1190 (November).

Sarel, M., 1996, "Nonlinear Effects of Inflation on Economic Growth," Staff Papers, International Monetary Fund, Vol. 43, pp. 199-215 (March).

Siklos, P., 2002, The Changing Face of Central Banking: Evolutionary Trends Since World War II (Cambridge: Cambridge University Press).

Truman, E., 2003, Inflation Targeting in the World Economy, Institute for International Economics, Washington, D.C. 